\title{
An analysis of modified human teeth at Neolithic Çatalhöyük, Turkey
}

Haddow, Scott D.; Tsoraki, Christina; Vasi, Milena; Dori, Irene; Knüsel, Christopher J.; Milella, Marco

Published in:

Journal of Archaeological Science: Reports

DOI:

10.1016/j.jasrep.2019.102058

Publication date:

2019

Document version

Peer reviewed version

Document license:

CC BY-NC-ND

Citation for published version (APA):

Haddow, S. D., Tsoraki, C., Vasi, M., Dori, I., Knüsel, C. J., \& Milella, M. (2019). An analysis of modified human teeth at Neolithic Çatalhöyük, Turkey. Journal of Archaeological Science: Reports, 28, [102058].

https://doi.org/10.1016/j.jasrep.2019.102058 


\section{An Analysis of Modified Human Teeth at Neolithic Çatalhöyük, Turkey}

Scott D. Haddow ${ }^{1}$, Christina Tsoraki ${ }^{2}$, Milena Vasić ${ }^{3}$, Irene Dori ${ }^{4}$, Christopher J. Knüsel ${ }^{4}$ and Marco Milella ${ }^{5}$

\section{Highlights}

- Three apparently modified human teeth found in various contexts at Neolithic Çatalhöyük, Turkey

- Radiographic and microscopic analyses confirm intentional modification and extensive usewear in two of the three teeth. Third tooth is less clear.

- Two of the three teeth investigated represent first documented examples of artificially modified human teeth in prehistoric Near East

- These two teeth were manufactured using the same technical skills/toolkits used to produce other bead types at Çatalhöyük

- Confirmed cases derive from non-burial contexts. 


\section{An Analysis of Modified Human Teeth at Neolithic Çatalhöyük, Turkey}

Keywords: Anatolia; Near East; microwear analysis; personal adornment; material culture

Scott D. Haddow ${ }^{1}$, Christina Tsoraki ${ }^{2}$, Milena Vasic ${ }^{3}$, Irene Dori ${ }^{4}$, Christopher J. Knüsel ${ }^{4}$ and Marco Milella ${ }^{5}$

${ }^{1}$ Department of Cross-Cultural and Regional Studies, University of Copenhagen, $2300 \mathrm{KBH}$ S, Denmark

${ }^{2}$ School of Archaeology and Ancient History, University of Leicester, LE1 7RH, United Kingdom

${ }^{3}$ Independent researcher, Berlin, Germany

${ }^{4}$ UMR 5199, De la Prehistoire à l'Actuel: Culture, Environnement, et Anthropologie (PACEA), Bâtiment B8, Allée Geoffroy Saint-Hilaire, CS 50023, Pessac Cedex, France 33615

${ }^{5}$ Department of Physical Anthropology, Institute of Forensic Medicine, University of Bern, Sulgenauweg 40, Bern 3007, Switzerland 


\section{Abstract}

The use of human teeth for ornamental purposes is archaeologically documented from the European Upper Palaeolithic, and, sporadically, during the subsequent Mesolithic, Neolithic and Chalcolithic periods. To date, no examples of this practice are available for the Near East during this timeframe. This contribution presents three human teeth from Neolithic Çatalhöyük (Central Anatolia, Turkey; 7100-6000 cal BC) that appear to have been modified for use as pendants. Macroscopic, microscopic and radiographic analyses confirm the modification and use of two out of three of these finds. The two confirmed pendants were likely extracted from the skeletonised remains of mature and old adults, carefully drilled, and worn for a variable period of time. The rarity of such artefacts in the prehistoric Near East suggests a profound symbolic meaning for this practice and these objects, and provides new insights into the funerary customs and symbolic importance of the use of human body parts during the Neolithic of the Near East.

\section{Introduction}

The intentional modification of human remains for ornamental, symbolic or utilitarian purposes is ethnographically and archaeologically attested in a variety of geographical and chronological contexts (e.g. Bello et al. 2017; Fairfield 1937; Jacobi 2007; McVicker 2005; Mensforth 2007; Meza Peñaloza 2007; Newton 1989; Pereira 2005; Skinner and Phillipps 1953; Stefanović 2006; Talavera et al. 2002). The earliest evidence of such practices in Western Eurasia dates to the Middle and Upper Palaeolithic (Buisson and Gambier 1991; Henry-Gambier and White 2006; Le Mort 1985; Le Mort and Gambier 1991; Patou-Mathis 1997; Rougier et al. 2016; Vercoutère et al. 2008; Verna and d'Errico 2011), and has been interpreted in various ways, with some scholars postulating a link to funerary rites involving defleshing of the dead, (possible) ritual cannibalism and subsequent working of selected bones. In the Near East the earliest known examples of intentionally modified human bone date to the Neolithic period in eastern Turkey (Gresky et al. 2017), with later findings dating to the Late Chalcolithic and Bronze Age of Syria (Sołtysiak 2010; McMahon et al. 2011; Molleson 2002), as well as the Late Bronze Age in Iran (Sołtysiak and Gręzak 2015). With the exception of the material from Neolithic Turkey, which involved perforated and deeply incised cranial vault fragments, bones in these instances were modified for use as utilitarian tools such as spindles and chisels. In addition to modified human bone, intentionally modified human teeth used as items of personal adornment also appear in the archaeological record of the European Upper Palaeolithic (Le Mort 1985; Vercoutère et al. 2008) and continued into the Mesolithic and Neolithic periods (Albrethsen and Brinch-Petersen 1976; Broglio et al. 2004; Ifantidis 2010, 2011; Mazzieri and Micheli 2014; Zagorakis 2004).

The ornamental use of human teeth and bone, a highly aesthetic and symbolic material choice, raises intriguing questions about the socio-cultural meaning(s) of this practice in prehistory. More specifically, these types of finds are of direct relevance when exploring the temporal and geographic patterns in the modification and use of human body parts for socio-cultural purposes among human societies.

This paper presents the analysis and discussion of three isolated human teeth from Neolithic Çatalhöyük (Central Anatolia) presenting features, in at least two cases, strongly suggestive of their intentional modification for ornamental purposes, the first such artefacts found and reported on in the Near East to date.

On the basis of a detailed macroscopic and microscopic examination of these finds, the following questions are addressed: 
1) Who were the individuals these teeth were taken from (age-at-death)?

2) Were the teeth taken from living individuals or corpses/skeletons?

3) Are there distinctive microwear traces present on the tooth surfaces that can be attributed to their intentional treatment, and what can be inferred about the relative degree and mode of use?

4) How do these artefacts fit within the symbolic landscape of Çatalhöyük and, more generally, of the Neolithic Near East?

\subsection{Archaeological context}

The archaeological site of Çatalhöyük (Central Anatolia, Turkey), is comprised of two separate mounds or tells. The larger East Mound dates to ca. 7100-6000 cal BC (Bayliss et al. 2015) and represents one of the most important and well-preserved Late Neolithic settlements in the Near East. The smaller West Mound dates to the Early Chalcolithic and was occupied until the middle of the $6^{\text {th }}$ millennium BCE (Orton et al. 2018). Covering an area of 13ha, the Neolithic East Mound is characterised by dense aggregations of mudbrick domestic structures interspersed with external spaces used for middens, animal penning and other activities related to daily life. Lacking large-scale, clearly identifiable public structures, the houses at Çatalhöyük appear to have served as the focal point not only for domestic activities such as craft production, food storage and processing, but also ritual behaviours such as intramural burials, placed deposits, wall paintings and other structural embellishments that attest to a rich symbolic system and a complex socio-cultural environment (Hodder and Cessford 2004).

During the Ian Hodder-directed Çatalhöyük Research Project (1993-2017) over 700 individuals were recovered from stratified Neolithic contexts (Larsen et al. 2019). With regard to funerary practices, flexed primary inhumations within houses are the dominant burial type for all ages and sexes. Individuals are typically buried in narrow oval pits under the eastern and northern platforms of the central habitation space, although the very young (prenates, neonates and infants) may also be found in side rooms or in the southern areas of the house near ovens and hearths (Boz et al. 2006; Boz and Hager 2013). Secondary deposits of human remains, often in association with primary burials, are observed less frequently (Haddow and Knüsel 2017; Haddow et al. in prep.). While the majority of intramural interments took place during the occupation phase of houses, a smaller number of interments took place during construction and abandonment phases. Intramural burials became increasingly rare towards the end of the occupation of the East Mound (Haddow et al. in prep; Marciniak, Filipowicz, et al. 2015), a trend that ultimately led to the complete disappearance of burials within the Chalcolithic settlement on the West Mound (Anvari et al. 2017; Biehl 2012).

Grave goods are relatively rare among burials at Çatalhöyük; the most common are artefacts related to bodily adornment - predominantly beads and pendants. These were made most often of stone, but also of shell, clay, animal bone and teeth, wood and copper (Fig. 1). Among osseous materials, animal teeth beads are present, albeit in low numbers, and they first appear at the end of the Early period of occupation (7100-6700 calBC) (Bains 2012; Bains et al. 2013; Vasić 2018; Vasić, Knüsel, et al. in prep). Other types of adornment occurring in burials, albeit not as commonly, include finger rings, fasteners ("belt hooks and eyes"), bangles, and boar tusk collars (Nakamura and Meskell 2013; Vasić 2018). Pigments and plaster occur occasionally in burials, and pigment residues are found directly on human 
bones, but also on artefacts interpreted as pigment applicators and shell containers, whilst lumps of pigments are also sometimes included (Boz and Hager 2013; Nakamura and Meskell 2013; Vasić 2018; Vasić, Knüsel et al. in prep.). Less common grave inclusions include wooden bowls, bone points, grinding tools, chert and obsidian flakes and blades, whereas elaborate items such as stone maceheads and axes, chert daggers, obsidian mirrors and projectile points also occur very rarely (Vasić, Knüsel et al. in prep. 2018; Tsoraki in prep.).

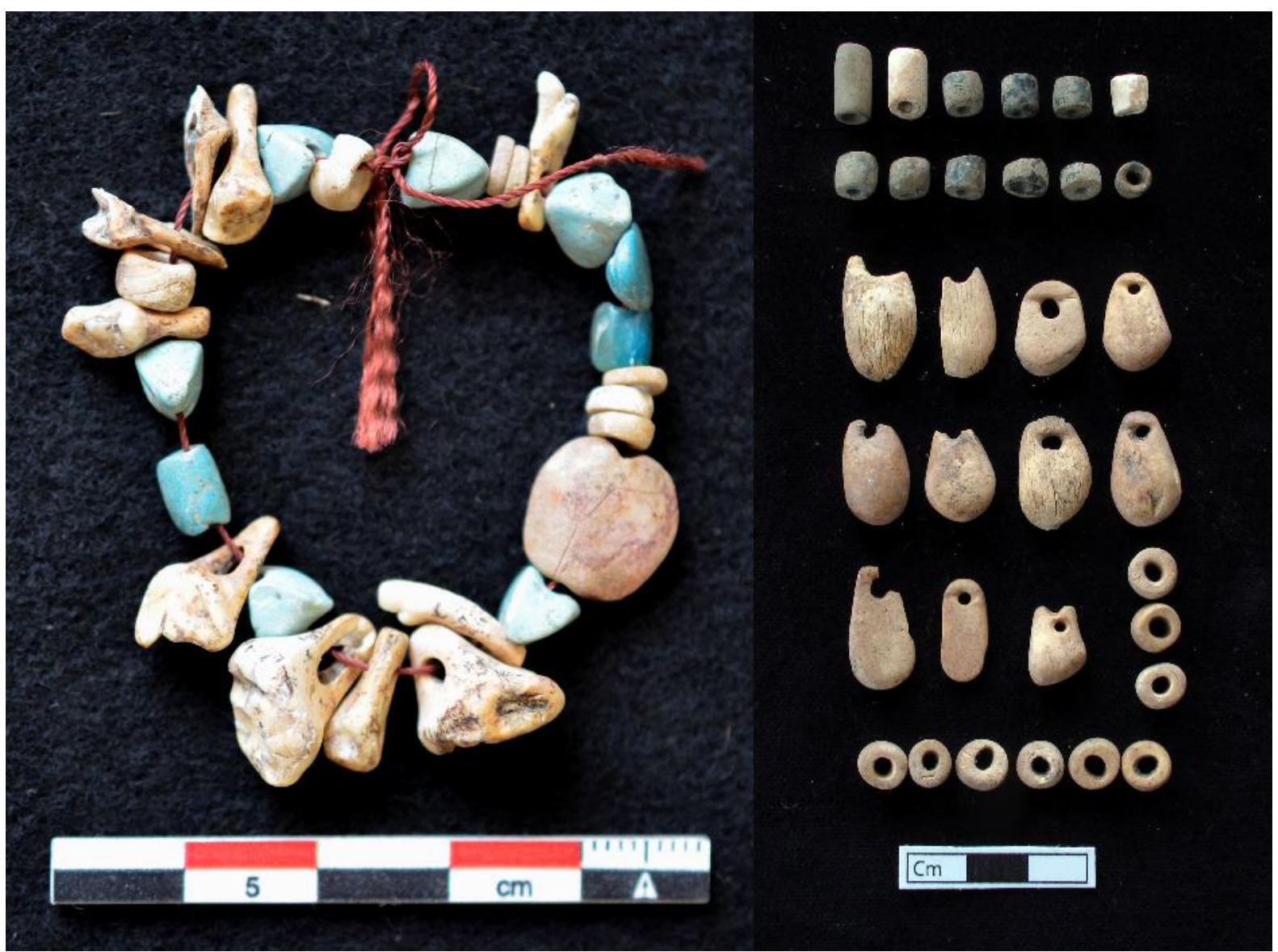

Figure 1: Examples of the diversity of bead styles and types at Çatalhöyük: (left) stone, animal teeth and bone bead anklet (11657.x2) from Neolithic burial of a child (photograph by Jason Quinlan); (b) stone and bone beads - including imitation (?) red deer canines - (32715.x2) possibly representing a necklace from a Neolithic burial of an old adult possible male (photograph by Ekin Ünal).

\section{Materials and methods}

The current study focuses on three human teeth recovered from the Neolithic occupation layers at Çatalhöyük. Two of these teeth (ID numbers 31375 and 30567.x2) show apparent signs of intentional modification in the form of a single perforation at the root. The third tooth (ID number 30008), although presenting less clear traces of anthropic modification, is considered here due to the presence of a perforation at the root in a roughly similar position and size to the ones observed on 31375 and 30567. The archaeological context of each tooth is described below. 


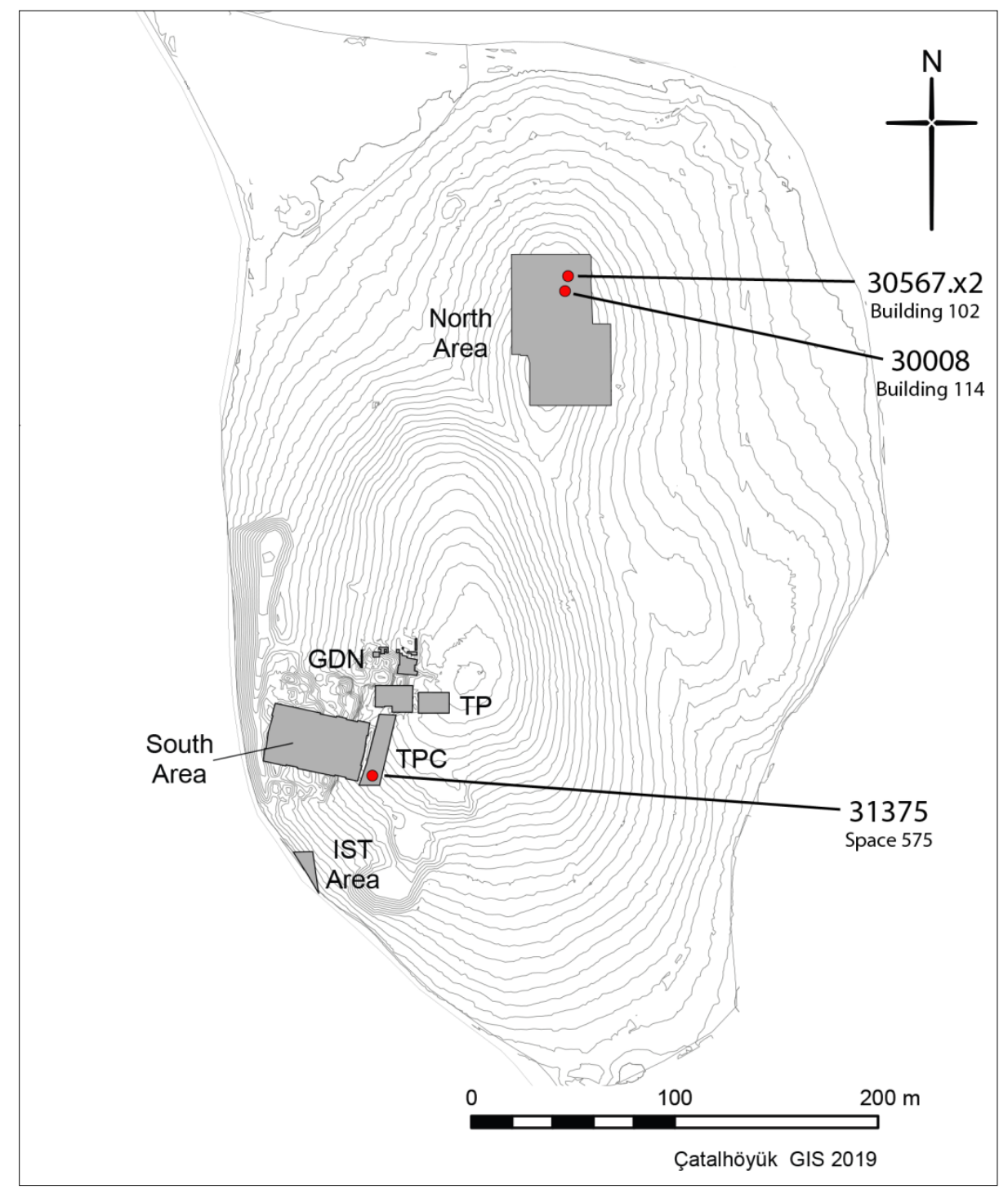

Figure 2: Map of the Neolithic East Mound at Çatalhöyük showing find locations for each of the teeth discussed (map by Camilla Mazzucato).

\section{Tooth 31375}

Tooth 31375 is a permanent lower right fourth premolar found in 2015 among the remains of a collapsed house wall located in Space 575 of the TPC Area (Fig. 2) attributed to the Late period of occupation of the site (6500-6300 calBC) (Marciniak, Baranski, et al. 2015; Fig. 3a). Because the tooth was recovered from the dry sieve, its precise relationship with the collapsed wall is unclear. 


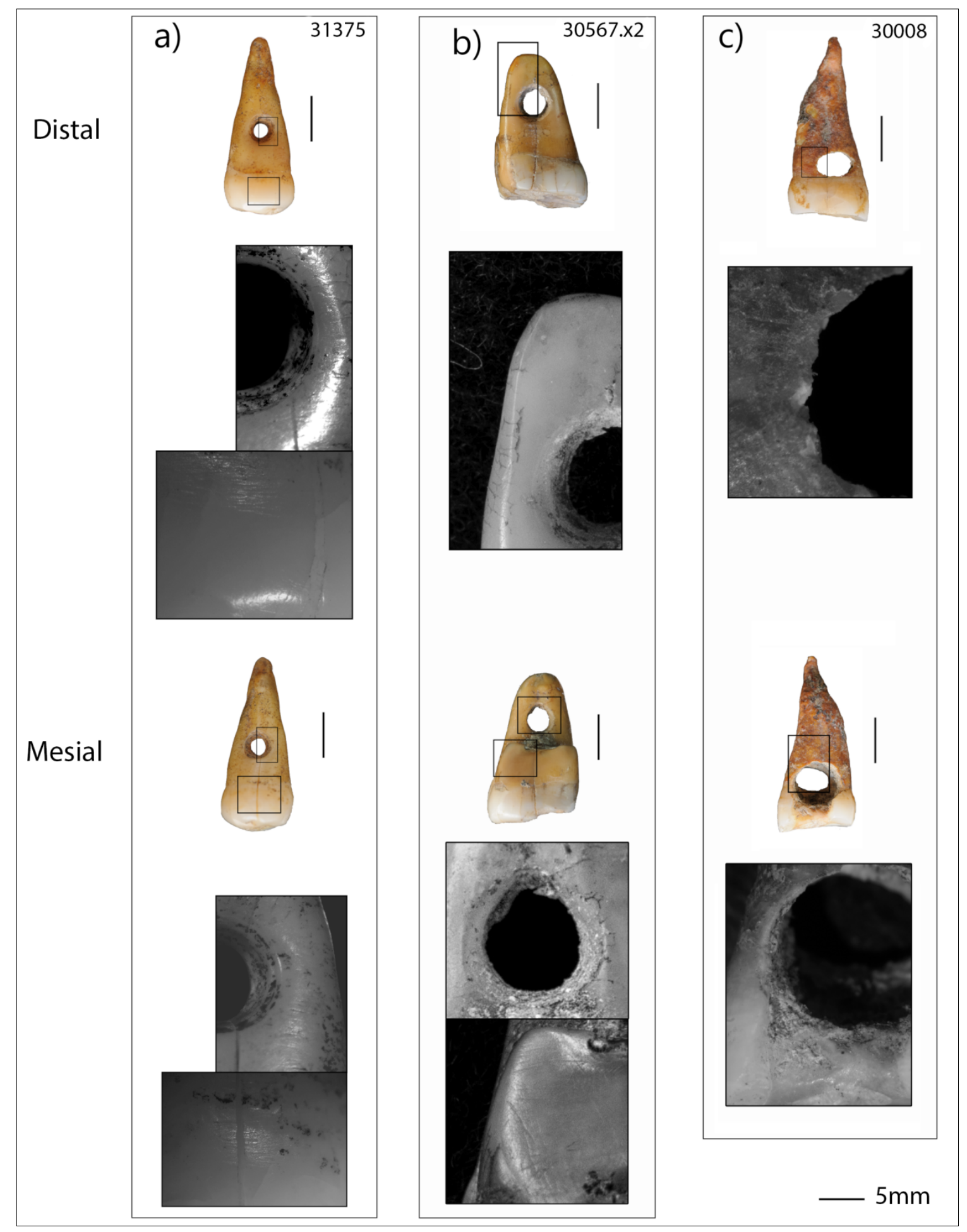

Figure 3: (a) permanent mandibular right fourth premolar (31375); (b) permanent mandibular right second molar (30567.x2); and (c) permanent maxillary right fourth premolar (30008). Distal (top) and mesial (bottom) views, and details of surface modifications (rectangles and corresponding greyscale images). Note the circular and regular shape of the root perforation in both 31375 and 30567.x2, and the polished surface of the root and crown, all features absent from 30008 .

\section{Tooth 30567.x2}

Tooth 30567.x2 is a permanent lower right second molar (Fig. 3b). It was found in 2013 within a post-retrieval pit near the west wall of Space 18, a side room within Building 102 located in the North Area of the site (Fig. 2) and attributed to the Middle period of 
occupation (6700-6500 calBC) (Tung 2013). Stratigraphically, this layer is associated with the abandonment phase of the building. A mini clay ball, a ground stone fragment and a cattle mandible were recovered nearby within the same layer. While no other beads or pendants were recovered from this deposit, a few beads, including one drilled cattle/red deer incisor was found within another deposit associated with the abandonment phase of Building 102, and a small number of beads, including two Antalis shell beads, were found in layers associated with the latest occupation phase. Furthermore, a large number of beads of various material types were found in subfloor burials in the northeast part of the building (Space 17).

\section{Tooth 30008}

Tooth 30008 is a permanent upper right fourth premolar (Fig. 3c). It was recovered in 2015 from the grave fill of an intramural primary burial. The burial (Feature 8100) contained a young adult male (Sk.30007) and an infant aged ca. 18 months (Sk.30010) (Haddow et al. 2015: 88). This double burial represents one of a series of inhumations that took place under the southeast platform of the main room of Building 114, located in the North Area of the site (Fig. 2) and attributed to the Middle period of occupation (6700-6500 calBC). The tooth was recovered during dry-sieving of the grave fill, so its relationship with either skeleton is unclear. The grave fill also contained a complete sub-spherical macehead (Tsoraki 2015) that was found in association with (Sk.30007) and a fragment from a bone point.

\subsection{Analytical approaches}

All teeth were examined macroscopically with the aid of a hand lens and digitally photographed with a Nikon $60 \mathrm{~mm}$ macro lens. With the exception of 30567.x2, which is currently curated at the Konya Archaeological Museum and not available for further study, the teeth were also examined and photographed with a Leica stereomicroscope in order to characterise extant pathological lesions, extent of occlusal wear, technological traces and usewear patterns. High precision dental silicone casts (made with Provil Novo Light) of specimens 31375 and 30008 permitted further analysis of microwear traces with an incident light microscope (Leica DM1750 M equipped with a LEICA MC120 HD digital camera) at $100 \times$ and 200× magnifications (high power approach, Keeley 1980, Van Gijn 1990). Attributes recorded include micropolish features, texture and distribution, microstriations, rounding, microfractures and deformation of perforation. Interpretation of recorded attributes was established by reference to other microwear studies, including studies focusing on wear development on prehistoric and ethnographic ornaments (e.g. Falci et al. 2019; Mărgărit 2016, in press; Marreiros et al. 2015 and chapters therein; Van Gijn 1990, 2014). In addition, digital radiographs of specimens 31375 and 30008 were taken using a Kevex PXS10-16W Microfocus X-ray source and a Varian System Flat Panel Amorphous Silicon Digital X-Ray Detector-PaxScan 4030R.

Lacking infra-cranial elements, estimation of the age-at-death of each individual was performed on the basis of the degree of crown wear. The latter was scored according to Smith (1984) on the three specimens and on a comparative sample including all adult individuals from Çatalhöyük preserving each tooth type (upper fourth premolar: $\mathrm{N}=53$, lower fourth premolar: $\mathrm{N}=59$, lower second molar: $\mathrm{N}=53$ ) on at least one side of the jaw. Age-at-death for the comparative sample was estimated on the basis of degenerative changes of the auricular surface and pubic symphysis (Lovejoy 1985; Brooks and Suchey 1990), and then grouped in three age classes (Young adult: 20-35 years old, Mature adult: 35-50 years old, and Old adult: $50+$ years old). For each tooth class, the probability of belonging to an age class was calculated, given a specific stage of crown wear by applying a Random Forest algorithm (2000 trees) to the comparative sample, using crown wear (on the right side, and on the left 
side if the former was missing) to classify individuals according to age-at-death. Random Forest is a learning algorithm that combines different randomised decision trees and averages their resulting predictions (Breiman 2001). Statistical analyses were performed with the randomForest package (Liaw and Wiener 2002) in R 3.5.1 (R Core Team 2018).

\section{Results}

\section{Tooth 31375}

Age estimation and observable pathological lesions: The relatively moderate occlusal wear (grade: 5), suggests that the tooth belonged to a middle adult (36-49 years old) individual (Fig. 4). No pathological features are observable. 


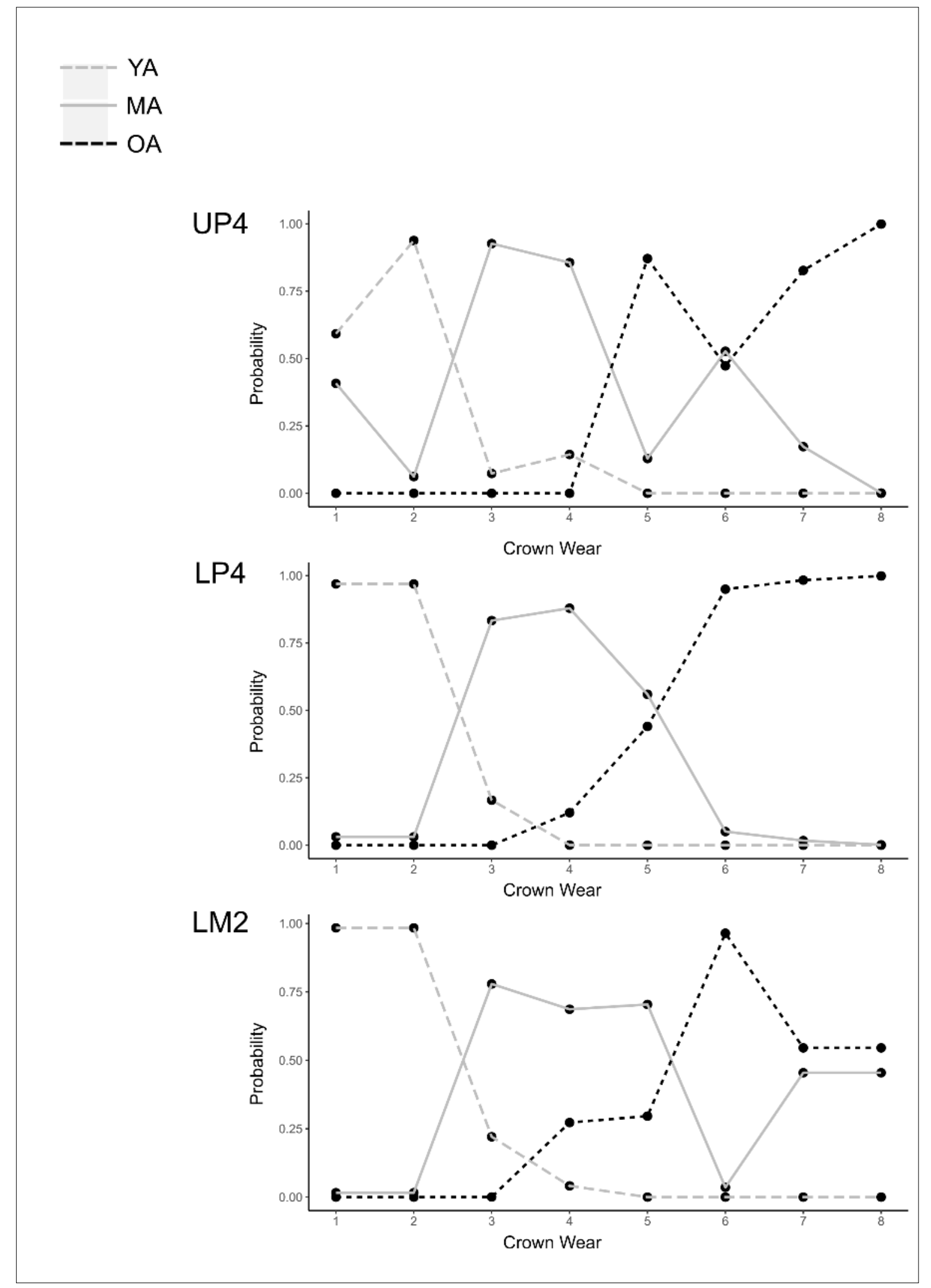

Figure 4: Probability of an individual falling into one specific age class based on the degree of dental crown wear. Probabilities are calculated by means of a Random Forest algorithm. YA= young adult; MA=mature adult; OA= old adult; UP4=upper fourth premolar; LP4=lower fourth premolar; LM2= lower second molar. 
Modifications and microwear traces: The tooth retains its natural form and features a biconically drilled perforation (diameter: $1.7 \mathrm{~mm}$ ) that completely pierces the root mesiodistally, ca. $5.0 \mathrm{~mm}$ from the crown (Figs $3 \mathrm{a}$ and $7 \mathrm{a}$ ). The rim of the perforation is circular with well-defined and regular edges, and presents concentric striations on the interior of the perforation. The rim of the perforation exhibits rounding and polish; rounding and smoothing is also visible in the interior of the perforation that have partially obliterated the drilling traces. Further polish, with clear directionality (perpendicular to the long axis of the tooth), and rounding, are observed on the tooth surfaces around the perforation. Under high magnification the microtopography of the tooth root surface shows rounding and a welldeveloped reflective micropolish that has a greasy appearance, extends to the microtopography of the root surface superior to the perforation and is accompanied by multidirectional striations of varying lengths (Fig. 5). Localised micropolish is present on the rim of the perforation, but no particular areas with more developed wear traces are visible. Similarly, on the walls of the perforation localised use-related micropolish with a directionality perpendicular to the concentric striations overlays the production traces (Fig. $6)$.

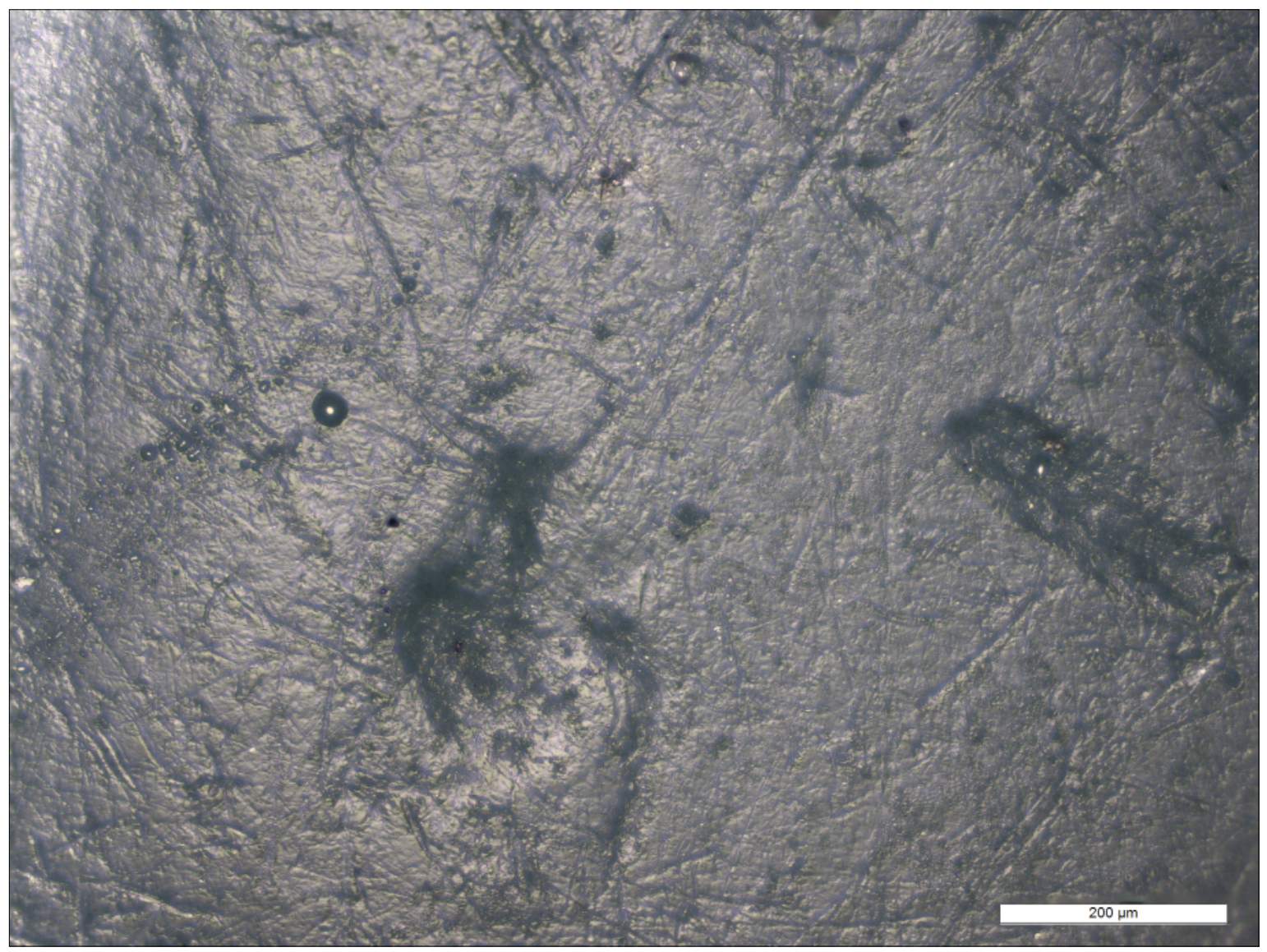

Figure 5: Micrograph of mesial tooth root surface of 31375 (superior to perforation) showing well-developed micropolish accompanied by multi-directional striations of varying length. 


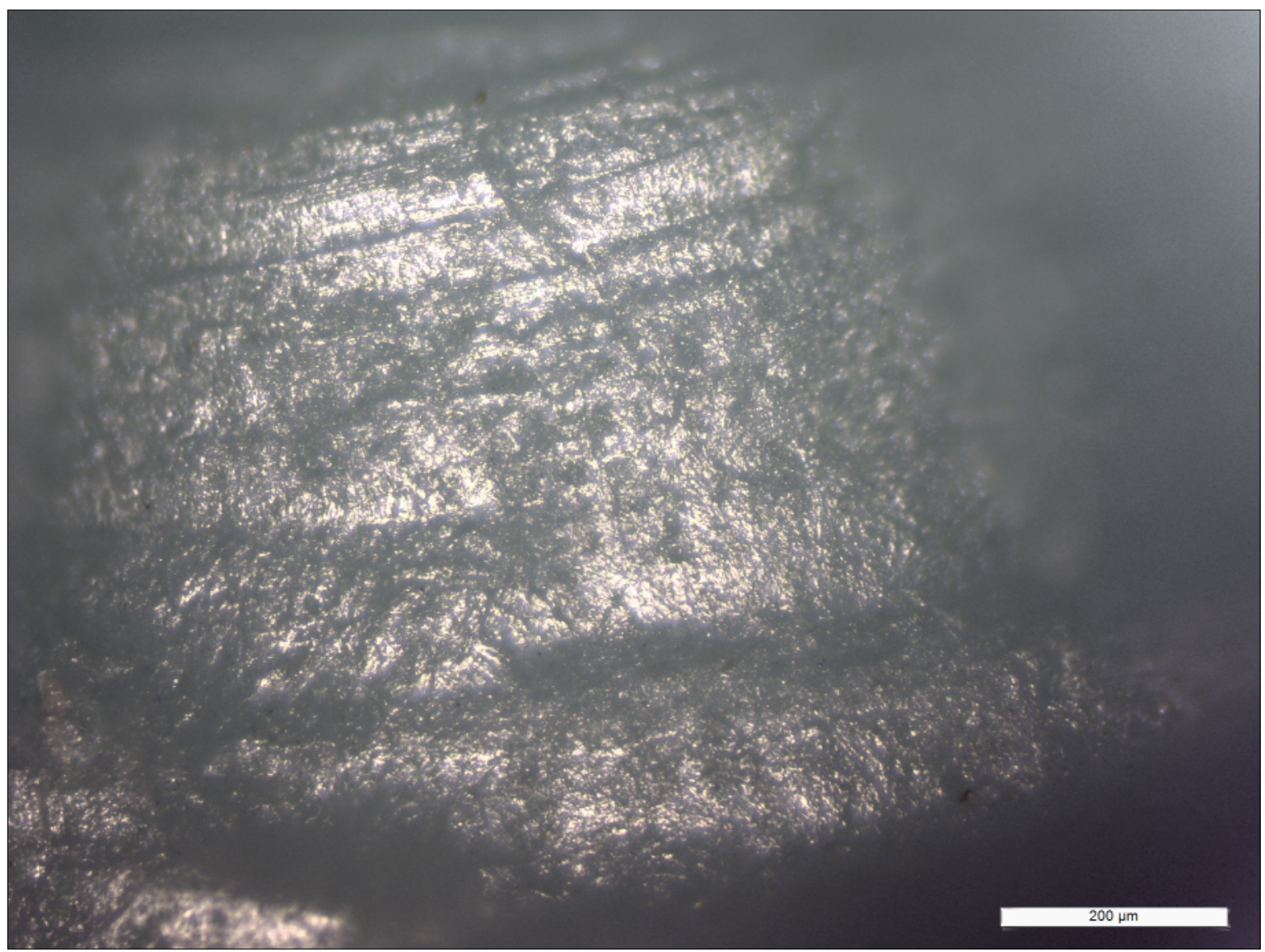

Figure 6: Micrograph of the walls of the root perforation on 31375 showing localised use-related micropolish oriented perpendicular to the concentric striations produced during the drilling of the tooth.

\section{Tooth $30567 . x 2$}

Age estimation and observable pathological lesions: Occlusal wear (grade: 6) is substantial and places this individual in the old adult age class (Fig. 4). No pathological features were observed on the crown or root surfaces. The tooth is missing the mesial root, possibly due to a post-mortem breakage during extraction of the tooth from the alveolar process.

Modifications and microwear traces: A biconically drilled perforation (diameter: ca. $2.0 \mathrm{~mm}$ ) completely pierces the distal root mesiodistally, ca. $5.0 \mathrm{~mm}$ from the crown (Fig. $3 \mathrm{~b}$ ). The perforation has a circular and well-defined rim, and the perforation wall exhibits fine concentric striations. Although the specimen retains many of its natural features and form, the crown and root surfaces have been significantly modified by abrasion and polishing; a grinding facet is visible near the base of the broken mesial root and the distal root tip has been heavily blunted. All traces of the fractured mesial root have been smoothed over and polished suggesting an interest in achieving a smooth and uniform appearance. Macroscopically visible rounding and smoothing accompanied by multi-directional striations are visible on the tooth surface. Apart from ante-mortem wear, the occlusal surface of the crown does not appear to have been altered post-mortem, although the enamel on the buccal surface of the crown has been completely worn away and potentially polished further.

\section{Tooth 30008}

Age estimation and observable pathological conditions: Crown wear is stage 5, which suggests it derives from a middle/old adult individual (Fig. 4). The tooth presents a gross 
interproximal carious lesion (diameter $=5.0 \mathrm{~mm}$, score 8 (Hillson 2001)), likely originating at the mesial cemento-enamel junction and penetrating to the distal root surface (maximum diameter $=2.8 \mathrm{~mm}$ ). Fresh breaks at the margins of the opening on the distal root surface (as well as the mesial surface) indicate that the original breach may have been smaller.

Modifications and microwear traces: Unlike the other specimens, no clear drilling marks are visible in this case. Rather, the rim of the perforation on the mesial and (especially) distal root surfaces are relatively discontinuous, with a rugged appearance (Fig. 3c). The discontinuous appearance of the perforation is further confirmed when this tooth is compared radiographically with specimen 31375 . In the latter, the biconical shape of the mesial and distal drilling is quite evident, as well as the v-shaped and almost mirrored upper and lower margins of the root perforation (Fig. 7a). These features are absent from specimen 30008, where the mesial and distal perforations, and the upper and lower margin of the root discontinuity, are irregular (Fig. 7b). Localised rounding and polish, however, is visible on two diametrically opposed areas on the rim of the perforation observed on the distal surface of the specimen, but the mesial surface does not exhibit similar macroscopically visible rounding; under high magnification no developed microscopic wear traces (micropolish, smoothing, rounding) are observed on the tooth surface around the perforation. Furthermore, no artificial smoothing is present on either the crown or root, the only visible crown wear likely being the by-product of ante-mortem occlusal attrition. 
a) 31375
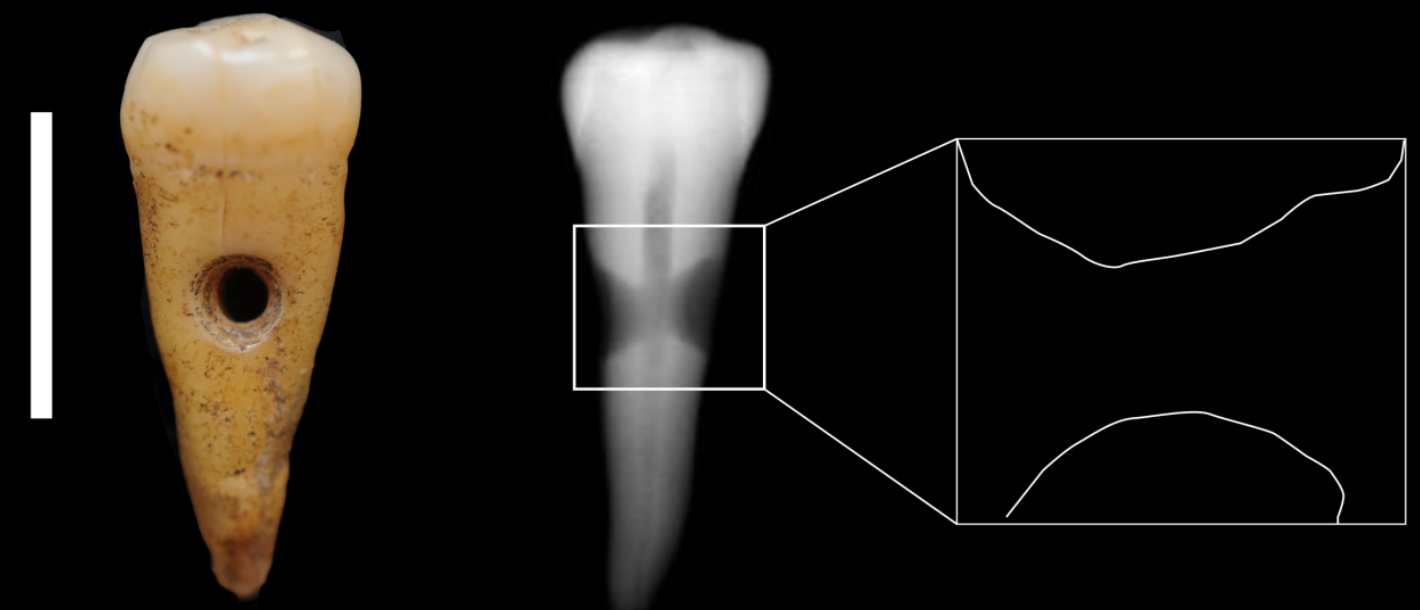

\section{b) 30008}
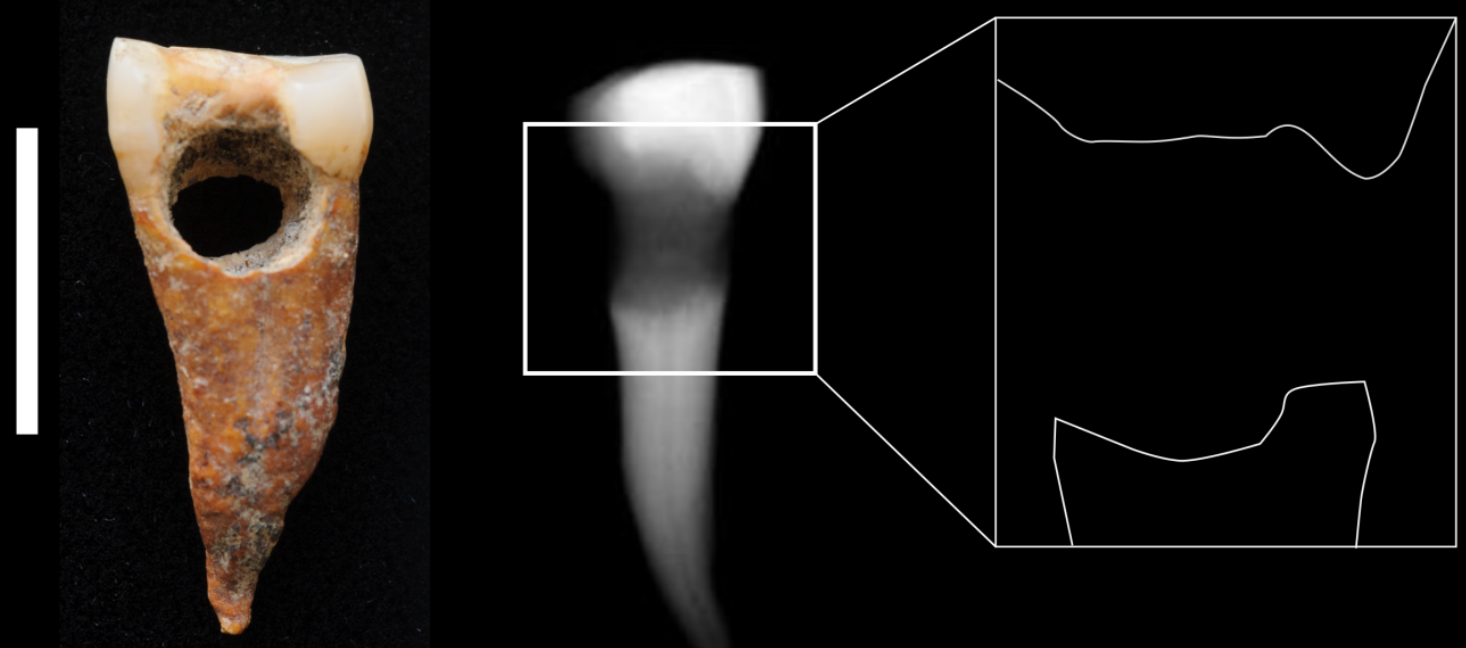

\section{$10 \mathrm{~mm}$}

Figure 7: X-ray images of (a) 31375 and (b) 30008 along the mesiodistal plane, and profiles of the upper and lower margins of the root perforations. Note the irregular appearance of the latter in 30008 . 


\section{Discussion}

The results of this study allow us to address our original research questions:

\section{(1) Who were the individuals these teeth were taken from (age-at-death)?}

Age-at-death estimates based on observations of occlusal wear on each tooth place all three individuals in the middle to old adult age range. The possible link between the relatively advanced age of an individual and the use of their teeth as a pendant cannot be tested on the basis of only three specimens, especially lacking comparative data for the Neolithic Near East. It is interesting to note that Bonogofsky (2005), in her analysis of plastered skulls from Köşk Höyük (Neolithic Anatolia), did not find any association between advanced age and secondary treatment, a result that argues against some form of ancestor worship underlying other types of age-based selection in such practices (and possibly also the re-use of teeth). However, analyses of grave good provisioning, dietary patterns and other data sets at Çatalhöyük suggest that age, rather than sex or other social categories may have been the main driver of social differentiation at the site (Haddow et al. in prep.; Knüsel et al. in prep.; Nakamura and Meskell 2013; Pearson and Meskell 2013; Pearson et al. 2015; Vasić 2018; Vasić, Knüsel et al. in prep.). In light of these previous observations, the ages of the two individuals involved here may have played a role in their selection.

\section{2) Were the teeth taken from living individuals or corpses/skeletons?}

Specimens 30567.x2 and 31375 lack observable pathological features (e.g. carious lesions) that typically contribute to ante-mortem tooth loss; based on this evidence, it is more likely that these teeth were intentionally extracted. Furthermore, due to their complex root structure, molars are not easily extracted from the alveolar process without damage to the roots. This is especially relevant when considering 30567.x2, which is missing its mesial root. On this basis, it appears that these teeth were acquired post-mortem. While it is possible that these teeth were intentionally extracted from living individuals, this scenario is less likely (see below). Specimen 30008, on the other hand, may have been lost ante-mortem as a result of the gross interproximal carious lesion leading to tooth necrosis and subsequent extraction/exfoliation.

\section{3) Are there distinctive microwear traces present on the teeth surfaces that can be attributed to their intentional treatment and what can be inferred about the relative degree and mode of use?}

Two of the three examined teeth (31375 and 30567.x2) present clear features of intentional modification and subsequent stringing likely in the context of their use as ornamental objects. The general appearance of the perforations and the concentric striations on their walls suggest that the roots of both teeth were drilled using mechanical drilling with a conically-shaped microdrill. The application of mechanical drilling is consistent with technological choices reflected in the Çatalhöyük ornament technologies more broadly (Bains et al. 2013, Vasić, Siebrecht, et al. in prep.). Moreover, it suggests that the perforation of the human teeth was a task performed by individuals who possessed the required knowledge of technological gestures, material properties and appropriate tool kits (e.g. bow drills, flint and obsidian microdrills). The post-mortem smoothing, rounding and greasy appearance observed on the crowns and roots of both items is consistent with their use (suspension), and their contact with a relative soft contact material such as human skin or clothing (cf. Falci et al. 2019). The facet on the distal part of the root of 30567 is probably related to the suspension mechanism used and indicates a prolonged use of the drilled tooth. The lack of similar features on 31375 most likely indicates the use of a different suspension method. Overall, the lack of areas with differentially developed microwear traces, along with the well-preserved 
perforation rim, suggest that 31375 was not tightly attached to a string or clothing. Furthermore, the fact that the manufacturing wear traces on the interior of the perforation had not been eradicated completely through subsequent wear permits consideration of the relative degree of use of this tooth as a pendant. While the tooth was used for a considerable amount of time for wear traces to develop, suspension was not prolonged enough to completely erase the existing manufacturing traces. Overall, both drilled teeth present consistent wear patterns suggesting extended use as ornaments.

Tooth 30567 bears similarities with the drilled lower left human first molar from Neolithic Dispilio, Greece (Ifantidis 2010, 2011): both teeth are double-rooted but only one root is perforated (the mesial root in the case of the Dispilio specimen), while the opposite root is broken. However, the crown and root surfaces of 30567.x2 are more heavily worn than those of the Dispilio specimen. Because the Dispilio tooth was discovered during postexcavation analyses of bags containing bones, its original find context is unclear (Ifantidis 2010).

The case of 30008 is less straightforward, however, given a) the lack of drilling traces, b) the absence of clear use-wear traces indicative of post-mortem use, and c) the presence of a carious lesion penetrating the entire mesio-distal diameter of the tooth root. The apparent artificial perforation in this case is the result of the carious process affecting the cemento-enamel junction. Interestingly, the features described for 30008 are similar to those observed on a human permanent lower fourth premolar from the Neolithic site of La Cabaña (southern Spain, $4^{\text {th }}$ millennium BC - Etxeberria and Rojo 1994). In this case, an apparent intentional perforation was revealed to be the result of a carious lesion penetrating the cemento-enamel junction. Altogether, these observations suggest that this tooth was most likely not used as a pendant, or at least if it had been used as a pendant, this use was of rather limited duration and did not result in extensive use-wear. Therefore this tooth is distinctly different to the intentionally modified teeth described here.

The concurrent use of objects with natural perforations (shells, stones), along with intentionally modified ones, is encountered more broadly within the Çatalhöyük ornamental traditions (Bains et al. 2013; Vasić 2018; Vasić, Siebrecht, et al. in prep.). Finally, it is worth noting that the interpretation of specimen 30008 is further complicated by the fact that there are no individuals within the sequence of burials in this platform from whom the tooth could potentially derive. On the basis of the available information, it is not possible to determine if its inclusion was due to casual processes such as loss, or rather the result of an intentional act (possibly motivated by the particular appearance of the tooth itself). It is likely, though, that it was introduced into the grave fill from elsewhere.

4) How do these artefacts fit within the symbolic landscape of Çatalhöyük and, more generally, of the Neolithic Near East?

At Çatalhöyük, as at many Neolithic Near Eastern sites, secondary burial practices associated with the retention and possible display of crania (with or without mandibles) would have provided easy access to human teeth. Furthermore, a sizeable proportion of the excavated skeletal assemblage at Çatalhöyük is made up of loose or partially articulated bones deriving from open spaces such as middens and building infill layers (Boz and Hager 2013; Haddow et al. in prep.). One long-standing explanation for the occurrence of human bone in these "tertiary" contexts is that it is the result of the circulation of soils from one area of the site to another for building construction and other activities (e.g. Boz and Hager 2013: 432). In terms of skeletal part representation, however, highly fragmented crania and mandibles are over-represented within this assemblage (Haddow et al. in prep.), which 
suggests a pattern of selective deposition perhaps associated with multi-stage funerary treatments. Regardless of interpretation, the relative abundance of fragmentary crania and mandibles in these open spaces would also have provided an ample source of human teeth. In light of this, others have suggested that perhaps loose teeth - separated from the jaw boneswould not have been recognisable as deriving from humans, and thus were treated as any other animal tooth. We find this scenario highly unlikely, however, given the intimate relationship the Neolithic inhabitants of Çatalhöyük appear to have had with the bodies and bones of their dead, in addition to a high level of familiarity with animal anatomy through the hunting, rearing and processing of various large mammal species.

Given the amount of disarticulated and fragmentary skeletal material often circulating within Neolithic sites, what is most interesting is the fact that human teeth and bone were not modified more often. At Çatalhöyük, beads made from animal teeth are rare as well. Also, given the availability of deciduous teeth and other single-rooted teeth shed during life, it is noteworthy that the only documented examples of intentionally perforated human teeth at Çatalhöyük are from the permanent dentition and were likely retrieved post-mortem. Taken together, these observations militate against a solely aesthetic purpose for the practice of tooth modification observed at Çatalhöyük. Rather, these material choices - and their rarity overall-suggest a deeper symbolic value, the full meaning of which cannot be fully appreciated at present.

Secondary depositions of human remains are well-documented in the Near Eastern Epi-palaeolithic and subsequent Neolithic periods, especially with regard to the retrieval, curation, and, in some cases, decoration of crania-with or without mandibles (e.g. Bonogofsky 2003, 2005; Bocquentin et al. 2016; Croucher 2012; Goren et al. 2001; Haddow and Knüsel 2017; Hodder 2007; Hodder and Meskell 2011; Rollefson 1983; Talalay 2004). During this time, it is possible to observe the development of a highly particular set of attitudes and behaviours toward the dead and their remains (Kuijt 1996, 2000), the ultimate meaning of which, however, is not fully understood. For example, the practice of skull retrieval has been interpreted in a variety of ways over the years; many researchers have argued it represents a form of ancestor veneration (Bienert 1991; Cauvin 1978, 1994; Goren et al. 2001; Kenyon 1956), although more recent research has shown that all age groups are represented (e.g. Bonogofsky 2005). The practice is now commonly interpreted as a way to reinforce social bonds and relieve societal tensions via collective ritual practices and the creation of shared social memory (Goring-Morris 2000; Kuijt 2000, 2001, 2008), although there may be multiple motivations and meanings associated with such behaviours (Haddow and Knüsel 2017; Santana et al. 2012, 2015; Schmandt-Besserat 2013). Independent from their specific symbolic meaning, the diachronic increase of archaeological evidence related to post-mortem manipulations of human remains indicates a clear change in the symbolic importance of the human body and interactions between the living and the dead. In light of this cultural preoccupation with skull retrieval and other secondary burial treatments, it is perhaps surprising that examples of worked human remains, including teeth, are so rare in the Near Eastern Neolithic. 
While the modification of human teeth for personal adornment in the Neolithic Near East has been - until now - completely undocumented, animal teeth were often modified for use as beads or pendants in prehistory (e.g. Kyselý et al. 2019). The most common example is that of red deer canine teeth and imitations thereof, which are found throughout Europe and the Near East as early as the Upper Palaeolithic (Baines et al. 2013; Bánffy 2008; Broglio et al. 2004; Choyke 2001; Jeunesse 2002; Leroi-Gourhan 1968; Rainio and Mannermaa 2014). With their globular crown and flattened root, red deer canines lend themselves well to modification as beads/pendants. At Çatalhöyük, however, genuine red deer canine pendants are rare-imitations made from large mammal bones are more common (Bains et al. 2013: 361; Russell and Griffitts 2013: 298). While both human and animal tooth beads at Çatalhöyük were biconically drilled (Bains et al. 2013: 361), a more detailed comparison of manufacturing techniques for both tooth types is not possible at this stage due to a lack of microwear studies. As with human teeth, perforated animal teeth are rare in the Near Eastern Neolithic period (Bains et al 2013: 362).

The occurrence of imitated forms clearly attests to the importance of the shape, i.e. it was important for them to be recognised as an animal tooth. These pendants, as well as perforated teeth of other animals, occur on site in both burial and non-burial contexts. What is interesting here is that the two clearly modified human teeth from Çatalhöyük were recovered from non-burial contexts. Given the diversity of bead types found within burials at the site, the lack of modified human teeth/bone among them-and their rarity overallsuggests a deliberate choice in how these artefacts were used and disposed of, and when such uses were considered appropriate. There are potential parallels here with the rarity of bones/teeth of certain animal species at Çatalhöyük, particularly of bears, leopards, and vultures - especially as they play important roles in the symbolic repertoire of the site. This rarity has been interpreted as relating to taboos against bringing the remains of such ritually potent animals into the settlement (Russell et al. 2013; Russell 2018a, b). These potential similarities require further investigation.

\section{Conclusion}

The two confirmed cases of modified human teeth presented in this paper represent the first examples of a practice previously undocumented in the Near East and expand the understanding of Neolithic socio-cultural practices in the region. In addition, the microwear analyses conducted here provide insights into the technical aspects of their production and use-life, demonstrating that they were produced by skilled individuals using the same techniques and tool kits used to manufacture other bead types at Çatalhöyük, including animal tooth beads and pendants.

Based on the maturity of the two individuals whose teeth were modified, a tentative argument can be made for age biases governing the selection and production of such artefacts. Given the small sample size, however, this interpretation cannot be substantiated at present. Could these teeth also have been selected based on the specific identities of the two individuals? Alternatively, the ready availability of loose human bone and teeth from a variety of contexts at Çatalhöyük might suggest that the identity of the individuals from whom these modified teeth derive did not play a role in their selection. In this scenario, perhaps such artefacts played a purely apotropaic role, independent of particular personae. It is surprising, then, that human teeth were not selected for modification more often. Perhaps specific ritual taboos dictated their use and disposal. While the ultimate meaning of the use of human teeth as pendants at Çatalhöyük remains elusive, an exclusively aesthetic purpose for this practice is unlikely given the rarity of such findings. New findings, at Çatalhöyük and 
elsewhere in the Near East, will help to better contextualise the artefacts discussed in this contribution.

\section{Acknowledgements}

The authors acknowledge the support of the following organizations: the French State under the auspices of the "Investments for the Future" Program, IdEx (Initiative d'Excellence) of the University of Bordeaux (reference ANR-10-IDEX-03-02) (CJK), the European Commission H2020 Marie Skłodowska-Curie Actions Program (grant 752626) (ID), Collaborative Projects of the France-Stanford Center for Interdisciplinary Studies (CJK, SDH), European Commission FP7-People Marie-Curie Actions Program (grant agreement 328862) (CT). We thank the Çatalhöyük Research Project and its Director, Ian Hodder, for the opportunity to study and publish these results. We are grateful to Lisa Guerre of the Çatalhöyük Project for her finds management acumen that make these and many other objects available for continued study. We thank Evan Garofalo for acquiring the X-ray images of the specimens presented in this study, and Ali Rezaee Vahdati for his advice on the statistical analyses. We would also like to acknowledge the assistance of Camilla Mazzucato, who produced the digitized map of the East Mound at Çatalhöyük, as well as Jason Quinlan and Ekin Ünal whose photographs appear in this contribution. Lastly, we are grateful to the two anonymous reviewers for their constructive comments on an earlier draft. 


\section{References}

Albrethsen, S.E. and E. Brinch-Petersen. 1976. Excavation of a Mesolithic cemetery at Vedbaek, Denmark. Acta Archaeologica 47: 1-28.

Anvari, J., J. Brady, I. Franz, G. Naumov, D. Orton, S. Ostaptchouk, E. Stroud, P.T. Willett, E. Rosenstock and P.F. Biehl. 2017. Continuous change: venturing into the early Chalcolithic at Çatalhöyük, In: The Archaeology of Anatolia Volume II: Recent Discoveries (2015-2016), edited by S.R. Steadman and G. McMahon. Lady Stephenson Library, Newcastle upon Tyne (UK): Cambridge Scholars Publishing, pp. 6-39.

Bains, R.K. 2012. The Social Significance of Neolithic Stone Bead Technologies at Çatalhöyük. PhD thesis: Institute of Archaeology, University College London.

Bains, R., M. Vasić, D.E. Bar-Yosef Mayer, N. Russell, K.I. Wright and C. Doherty. 2013. A technological approach to the study of personal ornamentation and social expression at Çatalhöyük. In Substantive Technologies at Çatalhöyük: Reports from the 20002008 Seasons, edited by I. Hodder. London: British Institute at Ankara; Los Angeles: Cotsen Archaeology Institute, pp. 331-364.

Bánffy, E. 2008. The deer tooth necklace from grave 12 at Bodrogzsadány. Acta Archaeologica 59(2): 163-169. https://doi.org/10.1556/AArch.59.2008.2.3

Bayliss, A., F. Brock, S. Farid, I. Hodder, J. Southon and R.E. Taylor. 2015. Getting to the bottom of it all: a Bayesian approach to dating the start of Çatalhöyük. Journal of World Prehistory 28(1): 1-26.

Bello, S.M., R. Wallduck, S.A. Parfitt and C.B. Stringer. 2017. An Upper Palaeolithic engraved human bone associated with ritualistic cannibalism. PLoS ONE 12(8): $\mathrm{e} 0182127$.

Biehl, P. 2012. The transition of the megasite Çatalhöyük in the Late Neolithic and Early Chalcolithic. In: Proceedings of the 7th International Congress on the Archaeology of the Ancient Near East. Volume I: Mega-Cities and Mega-Sites. The Archaeology of Consumption and Disposal, Landscape, Transport and Communication edited by R. Matthews and J. Curtis. Wiesbaden: Harrassowitz, pp. 17-34.

Bienert, H-D. 1991. Skull cults in the prehistoric Near East. Journal of Prehistoric Religion 5: 9-23.

Bocquentin, F., E. Kodaş and A. Ortiz. 2016. Headless but still eloquent! Acephalous skeletons as witnesses. Paléorient 42: 33-52.

Bonogofsky, M. 2003. Neolithic plastered skulls and railroading epistemologies. Bulletin of the American Schools of Oriental Research 331: 1-10.

https://doi.org/10.2307/1357755

Bonogofsky, M. 2005. A bioarchaeological study of plastered skulls from Anatolia: new discoveries and interpretations. International Journal of Osteoarchaeology 15(2): 124-135. https://doi.org/10.1002/oa.749

Boz, B. and L.D. Hager. 2013. Intramural burial practices at Çatalhöyük, Central Anatolia, Turkey. In: Humans and Landscapes of Çatalhöyük: Reports from the 2000-2008 Seasons, edited by I. Hodder. London: British Institute at Ankara; Los Angeles: Cotsen Institute of Archaeology Press, pp. 413-440. 
Boz, B., L.D. Hager, S.D. Haddow, S. Hillson, C.S. Larsen, C. Ruff, M.A. Pilloud, S. Agarwal, P. Beauchesne, B. Glencross and L. Gregorika. 2006. Human remains. In: Çatalhöyük 2006 Archive Report, pp. 157-171 http://www.catalhoyuk.com/archive reports/2006

Breiman, L. 2001. Random forests. Machine Learning 45: 5-32. https://doi.org/10.1023/A:1010933404324

Broglio, A., C. Cilli, G. Giacobini, A. Guerreschi, G. Malerba and G. Villa. 2004. Typological and technological study of prehistoric implements in animal hard tissues. Collegium Antropologicum 28(1): 55-61.

Brooks, S. and J.M. Suchey. 1990. Skeletal age determination based on the os pubis: a comparison of the Acsádi-Nemeskéri and Suchey-Brooks methods. Human Evolution 5: 227-238. https://doi.org/10.1007/BF02437238

Buisson, D. and D. Gambier. 1991. Façonnage et gravures sur des os humains d'Isturitz (Pyrénées-Atlantiques). Bulletin de la Société Préhistorique Française 88(6): 172177.

Cauvin, J. 1978. Les Premiers Villages de Syrie-Palestine du IXème au VIlème Millénaire av. J.-C. Lyon: Maison de l'Orient.

Cauvin, J. 1994. Naissance des Divinités, Naissance de l'Agriculture: La Révolution des Symboles au Néolithique. Paris: CNRS éditions.

Choyke, A. 2001. Late Neolithic red deer canine beads and their imitations. In: Crafting Bone - Skeletal Technologies through Time and Space (British Archaeological Reports, International Series 937), edited by A. Choyke and L. Bartosiewicz. Oxford: Archaeopress, pp. 251-266.

Croucher, K. 2012. Death and Dying in the Neolithic Near East. Oxford: Oxford University Press.

Etxeberria, F. and M. Rojo. 1994. Diente humano perforado procedente del megalito de La Cabaña (Sargentes de La Lora, Burgos): un ejemplo de tafonomía. Munibe Antropologia-Arkeologia 46: 117-122.

Falci, C.G., J. Cuisin, A. Delpuech, A. Van Gijn and C.L. Hofman, 2019. New insights into use-wear development in bodily ornaments through the study of ethnographic collections. Journal of Archaeological Method and Theory 26(2): 755-805. https://doi.org/10.1007/s10816-018-9389-8

Fairfield, F. 1937. A necklace of human teeth He Maioha Maukaki. The Journal of the Polynesian Society 46(183): 130-133.

Goren, Y., Goring-Morris, A.N. and I. Segal. 2001. The technology of skull modelling in the Pre-Pottery Neolithic B (PPNB): regional variability, the relation of technology and iconography and their archaeological implications. Journal of Archaeological Science 28(7): 671-690.

Goring-Morris, N. 2000. The quick and the dead: The social context of aceramic Neolithic mortuary practices as seen from Kfar HaHoresh. In: Life in Neolithic Farming Communities: Social Organization, Identity, and Differentiation, edited by I. Kuijt. Kluwer Academic/Plenum Publishers, New York, pp. 103-136. 
Gresky, J., J. Haelm and L. Clare. 2017. Modified human crania from Göbekli Tepe provide evidence for a new form of Neolithic skull cult. Science Advances 3(6): e1700564.

Haddow, S.D. and C.J. Knüsel. 2017. Skull retrieval and secondary burial practices in the Neolithic Near East: Recent insights from Çatalhöyük, Turkey. Bioarchaeology International 1(1-2): 52-71.

Haddow, S.D., C.J. Knüsel, B. Tibbetts, M. Milella and B. Betz. 2015. Human remains. In Çatalhöyük 2015 Archive Report, pp. 85-101. http://www.catalhoyuk.com/archive_reports/2015

Haddow, S.D., E.M.J. Schotsmans, M. Milella, M.A. Pilloud, B. Tibbetts, B. Betz and C.J. Knüsel. In prep. Funerary practices I: body treatment and deposition. In: Peopling the Landscape of Çatalhöyük: Reports from the 2009-17 Seasons, edited by I. Hodder. Çatalhöyük Research Project Series Volume 13. London: British Institute at Ankara.

Henry-Gambier, D. and R. White. 2006. Modifications artificielles des vestiges humains de l'Aurignacien ancien de la grotte des Hyènes (Brassempouy-Landes). Quelles significations? In: En el Centenario de Cueva de El Castillo: El Ocaso de los Neandertales, edited by V. Cabrera Valdez, F.B. Quirós Guidotti and J.M. Maíllo Fernández. Madrid: Ministerio de Educacion y Ciencia, pp. 71-88.

Hillson, S. 2001. Recording dental caries in archaeological human remains. International Journal of Osteoarchaeology 11: 249-89.

Hodder, I. 2007. Çatalhöyük in the context of the Middle Eastern Neolithic. Annual Review of Anthropology 36: 105-120. https://doi.org/10.1146/annurev.anthro.36.081406.094308

Hodder, I. and C. Cessford. 2004. Daily practice and social memory at Çatalhöyük. American Antiquity 69(1): 17-40. https://doi.org/10.2307/4128346

Hodder, I. and L. Meskell. 2011. A "curious and sometimes a trifle macabre artistry": some aspects of symbolism in Neolithic Turkey. Current Anthropology 52(2): 235-263. https://doi.org/10.1086/659250

Ifantidis, F. 2010. Anthropina dontia, "anthropina" kosmimata: Ena simeioma me aformi to K0325 apo to Neolithiko Dispilio Kastorias [Human teeth, "human" ornaments: A note on a human tooth pendant from Neolithic Dispilio, W. Macedonia, Greece]. In: IRIS: Meletes sti Mnimi tis Kathigitrias Angelikis Pilali-Papasteriou apo tous Mathites tis sto Aristoteleio Panepistimio Thessalonikis, edited by N. Merousis, L. Stefani M. Nikolaidou. Thessaloniki: Cornelia Sfakianaki Editions, pp. 201-211.

Ifantidis, F. 2011. Cosmos in fragments: Spondylus and Glycymeris adornment at Neolithic Dispilio, Greece. In: Spondylus in Prehistory. New Data and Approaches. Contributions to the Archaeology of Shell Technologies (British Archaeological Reports International Series 2216), edited by F. Ifantidis and M. Nikolaidou. Oxford: Archaeopress, pp. 123-137.

Jacobi, K.P. 2007. Disabling the dead. In: The Taking and Displaying of Human Body Parts as Trophies by Amerindians, edited by R.J. Chacon and D.H. Dye. New York: Springer, pp. 299-338.

Jeunesse, C. 2002. La coquille et la dent: Parure de coquillage et évolution des systèmes symboliques dans le Néolithique danubien (5600-4500). In: Matériaux, Productions, 
Circulations du Néolithique à l'Âge du Bronze, edited by J. Guilaine. Paris: Éditions Errance, pp. 49-65.

Keeley, L.H., 1980. Experimental Determination of Stone Tool Uses: A Microwear Analysis. Chicago: The University of Chicago Press.

Kenyon, K.M. 1956. Jericho and its setting in Near Eastern history. Antiquity 30(120): 184197. https://doi.org/10.1017/S0003598X00026818

Knüsel, C.J., M. Milella, B. Betz, I. Dori, E. Garofalo, B. Glencross, S.D. Haddow., M. Ledger, E. Anastasiou, P. Mitchell, J. Pearson, M. Pilloud, C.B. Ruff, J.W. Sadvari, B. Tibbetts, C.S. Larsen. in prep. Bioarchaeology at Neolithic Çatalhöyük: indicators of health and well-being, and lifeway in their social context. In: Peopling the Landscape of Çatalhöyük: Reports from the 2009-17 Seasons, edited by I. Hodder. London: British Institute at Ankara.

Kuijt, I. 1996. Negotiating equality through ritual: a consideration of Late Natufian and PrePottery Neolithic A period mortuary practices. Journal of Anthropological Archaeology 15: 313-336. https://doi.org/10.1006/jaar.1996.0012

Kuijt, I. 2000. Keeping the peace: ritual, skull caching, and community integration in the Levantine Neolithic. In: Life in Neolithic Farming Communities: Social Organization, Identity, and Differentiation, edited by I. Kuijt. New York: Kluwer Academic/Plenum Publishers, pp. 137-164.

Kuijt, I. 2001. Place, death and the transmission of social memory in early agricultural communities of the Near Eastern Pre-Pottery Neolithic. Archaeological Papers of the American Anthropological Association 10: 80-99.

Kuijt, I. 2008. The regeneration of life: Neolithic structures of symbolic remembering and forgetting. Current Anthropology 49(2): 171-197.

Kyselý, R., M. Dobeš and K. Svoboda. 2019. Drilled teeth and shell artefacts from a grave at Prague-Březiněves and a review of decorative artefacts made from animal material from Corded Ware culture in the Czech Republic. Archaeological and Anthropological Sciences 11: 87-131. https://doi.org/10.1007/s12520-017-0514-5

Larsen, C.S., C.J. Knüsel, S.D. Haddow, M.A. Pilloud, M. Milella, J.W. Sadvari, J. Pearson, C.B. Ruff, E.M. Garofalo, E. Bocaege, B.J. Betz, I. Dori and B. Glencross. 2019. Bioarchaeology of Neolithic Çatalhöyük reveals fundamental transitions in health, mobility, and lifestyle in early farmers. PNAS_116(26): 12615-12623.

Le Mort, F. 1985. Un exemple de modification intentionnelle: La dent humaine perforée de Saint-Germain-la-Rivière (Paléolithique supérieur). Bulletin de la Société Préhistorique Française 82(6): 190-192.

Le Mort, F. and D. Gambier. 1991. Cutmarks and breakage on the human bones from Le Placard (France): an example of special mortuary practice during the Upper Palaeolithic. Anthropologie 29(3): 189-194.

Leroi-Gourhan, A. 1968. The Art of Prehistoric Man in Western Europe. London: Thames and Hudson.

Lovejoy, C.O., R.S Meindl, T.R. Pryzbeck, and R.P. Mensforth 1985. Chronological metamorphosis of the auricular surface of the ilium: a new method for the determination of adult skeletal age at death. American Journal of Physical Anthropology 68, 15-28. 
Liaw, A. and M. Wiener. 2002. Classification and regression by randomForest. $R$ News 2(3), $18-22$.

Marciniak, A., M. Baranski, A. Bayliss, L. Czerniak, T. Goslar, J. Southon and R.E. Taylor. 2015. Fragmenting times: interpreting a Bayesian chronology for the Late Neolithic occupation of Çatalhöyük East, Turkey. Antiquity 89: 154-176.

Marciniak, A., P. Filipowicz, J. Hordecki, and P. Eklöv Pettersson. 2015. Excavations in the TPC Area. In Çatalhöyük 2015 Archive Report, pp. 72-83. http://www.catalhoyuk.com/archive_reports/2015

Mărgărit, M., 2016. Testing the endurance of prehistoric adornments: Raw materials from the aquatic environment. Journal of Archaeological Science 70, 66-81. https://doi.org/10.1016/j.jas.2016.04.009

Mărgărit, M., in press. Personal adornments in the Romanian Eneolithic: Local versus exotic raw materials. Quaternary International. https://doi.org/10.1016/j.quaint.2018.09.046

Marreiros, J.M., J.F. Gibaja Bao and N. Bucho (eds.), 2015. Use-Wear and Residue Analysis in Archaeology. New York: Springer.

Mazzieri, P. and R. Micheli. 2014. Tradizioni funerarie e ornamenti personali: alcune osservazioni dalla sfera VBQ emiliana alla luce delle ultime scoperte. In: Il Pieno Sviluppo del Neolitico in Italia (Museo Archeologico del Finale - Finale Ligure Borgo 8-10 giugno 2009), edited by M. Bernabò Brea, R. Maggi and A. Manfredini. Bordighera: Istituto Internazionale di Studi Liguri Museo Bicknell, pp. 323-330.

McMahon, A., A. Sołtysiak and J. Weber. 2011. Late Chalcolithic mass graves at Tell Brak, Syria, and violent conflict during the growth of early city-states. Journal of Field Archaeology 36: 201-220. https://doi.org/10.1179/009346911X12991472411123

McVicker, D. 2005. Notched human bones from Mesoamerica. Mesoamerican Voices 2: 131.

Mensforth, R.P. 2007. Human Trophy Taking in Eastern North America During the Archaic Period. In: The Taking and Displaying of Human Body Parts as Trophies by Amerindians, edited by R.J. Chacon and D.H Dye, Interdisciplinary Contributions to Archaeology. Boston, MA., Springer, pp. 222-277.

Meza Peñaloza, A. 2007. Estudio osteológico y functional de raspadores elaborados con frontales humanos en La Ventilla, Teotihuacan, temporada 92-94. Estudios de Antropología Biológica 13: 150-170.

Molleson, T. 2002. Two spindles made from human fibulae from Tell Nebi Mend, Syria. BANEA Newsletter 15: 10-11.

Nakamura, C. and L. Meskell. 2013. The Çatalhöyük burial assemblage. In: Humans and Landscapes of Çatalhöyük: Reports from the 2000-2008 Seasons, edited by Ian Hodder. London: British Institute at Ankara; Los Angeles: Cotsen Institute of Archaeology Press, pp. 441-466.

Newton, D. 1989. Mother Cassowary's bones: daggers of the East Sepik province, Papua New Guinea. Metropolitan Museum Journal 24: 305-325. https://doi.org/10.2307/1512887 
Orton, D., J. Anvari, C. Gibson, J. Last, A. Bogaard, E. Rosenstock and P. Biehl. 2018. A tale of two tells: dating the Çatalhöyük West Mound. Antiquity: 92(363): 620-639. https://doi.org/10.15184/aqy.2018.91

Patou-Mathis, M. 1997. Analyse taphonomique et paléoethnographique du matériel osseux de Krapina (Croatie): nouvelles données sur la faune et les restes humains. Préhistoire Européenne 10: 63-90.

Pearson, J.A. and L.M. Meskell. 2013. Isotopes and images: fleshing out bodies at Çatalhöyük. Journal of Archaeological Method and Theory 22: 461-482

Pearson, J.A., SD. Haddow, S.W. Hillson, C.J. Knüsel, C.S. Larsen, J.W. Sadvari. 2015. Stable carbon and nitrogen isotope analysis and dietary reconstruction through the lifecourse at Neolithic Çatalhöyük, Turkey. Journal of Social Archaeology 15: 210232

Pereira, G. 2005. The utilization of grooved human bones: a re-analysis of artificially modified human bones excavated by Carl Lumholtz at Zacapu, Michoacan, Mexico. Latin American Antiquity 16(3): 293-312. https://doi.org/10.2307/30042495

R Core Team. 2018. R: A Language and Environment for Statistical Computing. Vienna: R Foundation for Statistical Computing.

Rainio, R. and K. Mannermaa. 2014. Tracing the rattle of animal tooth pendants from the Middle Neolithic graves of Ajvide, Gotland, Sweden. World Archaeology 46: 332348. https://doi.org/10.1080/00438243.2014.909105

Rollefson, G.O. 1983. Ritual and ceremony at Neolithic 'Ain Ghazal (Jordan). Paléorient: 29-38.

Rougier, H., I. Crevecoeur, C. Beauval, C. Posth, D. Flas, C. Wißing, A. Furtwängler, Anja, M. Germonpré, A. Gómez-Olivencia, P. Semal, J. van der Plicht, H. Bocherens and J. Krause. 2016. Neandertal cannibalism and Neandertal bones used as tools in Northern Europe. Scientific Reports 6(1): 29005. https://doi.org/10.1038/srep29005

Russell, N. 2018a. Feathers and talons: birds at Neolithic Çatalhöyük, Turkey. Archaeological and Anthropological Sciences. doi.org/10.1007/s12520-018-0681-z

Russell, N. 2018b. Spirit birds at Neolithic Çatalhöyük. Environmental Archaeology. doi.org/10.1080/14614103.2017.1422685

Russell, N. and J.L. Griffitts. 2013. Çatalhöyük Worked Bone: South and 4040 Areas. In: Substantive Technologies at Çatalhöyük Reports from the 2000-2008 Seasons, edited by I. Hodder. London: British Institute at Ankara; Los Angeles: Cotsen Institute of Archaeology Press, pp. 277-306.

Santana, J., J. Velasco, A. Balbo, E. Iriarte, L. Zapata Peña, L. Teira, C. Nicolle, F. Braemer, and J.J. Ibáñez. 2015. Interpreting a ritual funerary area at the Early Neolithic site of Tell Qarassa North (South Syria, late 9th millennium BC). Journal of Anthropological Archaeology 37:112-127.

Santana, J., J. Velasco, J.J. Ibáñez and F. Braemer. 2012. Crania with mutilated facial skeletons: A new ritual treatment in an Early Pre-Pottery Neolithic B cranial cache at Tell Qarassa North (South Syria). American Journal of Physical Anthropology 149:205-216. 
Schmandt-Besserat, D. 2013. The plastered skulls. In Symbols at 'Ain Ghazal ('Ain Ghazal Excavation Reports Vol. 3), edited by D. Schmandt-Besserat. ex-oriente, Berlin, pp. 213-243.

Sołtysiak, A. 2010. Death and Decay at the Dawn of the City. Warsaw: Institute of Archaeology, University of Warsaw.

Sołtysiak, A. and A. Gręzak. 2015. Worked human femur from Gohar Tepe, Iran. International Journal of Osteoarchaeology, 25(3): 361-365. https://doi.org/10.1002/oa.2296

Skinner, H. and W. Phillipps. 1953. Necklaces, pendants, and amulets from the Chatham Islands and New Zealand. The Journal of the Polynesian Society 62(2): 169-195.

Smith, B.H. 1984. Patterns of molar wear in hunter-gatherers and agriculturalists. American Journal of Physical Anthropology 63: 39-56. https://doi.org/10.1002/ajpa.1330630107

Stefanović, S. 2006. Human rib as a pendant at the Early Bronze Age necropolis in Mokrin. Journal of the Serbian Archaeological Society 22: 243-251.

Talalay, L.E. 2004. Heady business: skulls, heads and decapitation in Neolithic Anatolia and Greece. Journal of Mediterranean Archaeology 17(2): 139-163.

Talavera, J.A., J.M. Rojas, M.E. Salas and L.A. González. 2002. Análisis tecnológico y funcional de algunos artefactos de hueso humano del Mundo Perdido, Tikal, Guatemala. Arqueología 32: 48-60.

Tsoraki, C., 2015. Ground stone. In Çatalhöyük 2015 Archive Report, pp.152-160. http://www.catalhoyuk.com/archive_reports/2015

Tsoraki, C., In prep. The ground stone technologies at Neolithic Çatalhöyük: issues of production, use and deposition. In: Materials at Çatalhöyük: Reports from the 20092017 Seasons, edited by I. Hodder. Çatalhöyük Research Project Series Volume 15. London: British Institute at Ankara.

Tung, B. 2013. Excavations in the North Area. In: Çatalhöyük 2013 Archive Report, pp. 8-44. http://www.catalhoyuk.com/archive_reports/2013

Van Gijn, A.L., 1990. The Wear and Tear of Flint: Principles of Functional Analysis Applied to Dutch Neolithic Assemblages. Analecta Praehistorica Leidensia 22.

Van Gijn, A.L., 2014. Science and interpretation in microwear studies. Journal of Archaeological Science, 48, 166-9. https://doi.org/10.1016/j.jas.2013.10.024

Vasić, M. 2018. Personal Adornment in the Neolithic Middle East: A Case Study of Çatalhöyük. Unpublished PhD Thesis, Institut für Vorderasiatische Archäologie, Freie Universität Berlin.

Vasić, M., C.J. Knüsel and S.D. Haddow. In prep. Funerary practices II: burial associations. In: Peopling the Landscape of Çatalhöyük: Reports from the 2009-17 Seasons, edited by I. Hodder. Çatalhöyük Research Project Series Volume 13. London: British Institute at Ankara.

Vasić, M., M. Siebrecht, C. Tsoraki and R. Veropoulidou (with contributions by V. GarciaDiaz). In prep. Beads and pendants in life and death: insights into the production, use and deposition of ornamental technologies at Çatalhöyük. In: Materials at 
Çatalhöyük: Reports from the 2009-2017 Seasons, edited by I. Hodder. Çatalhöyük Research Project Series Volume 15. London: British Institute at Ankara.

Vercoutère, C., G. Giacobini, and M. Patou-Mathis. 2008. Une dent humaine perforée découverte en contexte Gravettien ancien à l'abri Pataud (Dordogne, France). L'Anthropologie: 112(2): 273-283. https://doi.org/10.1016/j.anthro.2008.02.002

Verna, C. and F. d'Errico. 2011. The earliest evidence for the use of human bone as a tool. Journal of Human Evolution 60: 145-157. https://doi.org/10.1016/j.jhevol.2010.07.027

Zagorakis, F. 2004. Zvejniecki (Northern Latvia) Stone Age Cemetery. BAR (British Archaeological Reports) International Series 1292. Oxford: Archaeopress.

\section{Figure captions}

Figure 1: Examples of diversity of bead styles and types at Çatalhöyük: (left) stone, animal teeth and bone bead anklet (11657.x2) from Neolithic burial of a child (photograph by Jason Quinlan); (b) stone and bone beads - including (imitation?) red deer canines (32715.x2) possibly representing a necklace from Neolithic burial of an old adult possible male (photograph by Ekin Ünal).

Figure 2: Map of the Neolithic East Mound at Çatalhöyük showing find location of teeth (map produced by Camilla Mazzucato).

Figure 3: (a) permanent mandibular right fourth premolar (31375); (b) permanent mandibular right second molar (30567.x2); and (c) permanent maxillary right fourth premolar (30008). Distal (top) and mesial (bottom) views, and details of surface modifications (rectangles and greyscale images). Note the circular and regular shape of the root perforation in both 31375 and 30567.x2, and the polished surface of the root and crown, all features absent from 30008 .

Figure 4. Probability of an individual falling in one specific age class based on the degree of dental crown wear. Probabilities are calculated by means of a Random Forest algorithm. YA= young adult; $\mathrm{MA}=$ mature adult; $\mathrm{OA}=$ old adult; UP4=upper fourth premolar; LP4=lower fourth premolar; LM2= lower second molar.

Figure 5. Micrograph of mesial tooth root surface of 31375 (superior to perforation) showing well-developed micropolish accompanied by multi-directional striations of varying length.

Figure 6. Micrograph of the walls of the root perforation on 31375 showing localised userelated micropolish oriented perpendicular to the concentric striations produced during the drilling of the tooth. 
Figure 7. X-ray images of (a) 31375 and (b) 30008 along the mesio-distal plane, and profiles of the upper and lower margins of the root perforations. Note the irregular appearance of the latter in 30008 . 


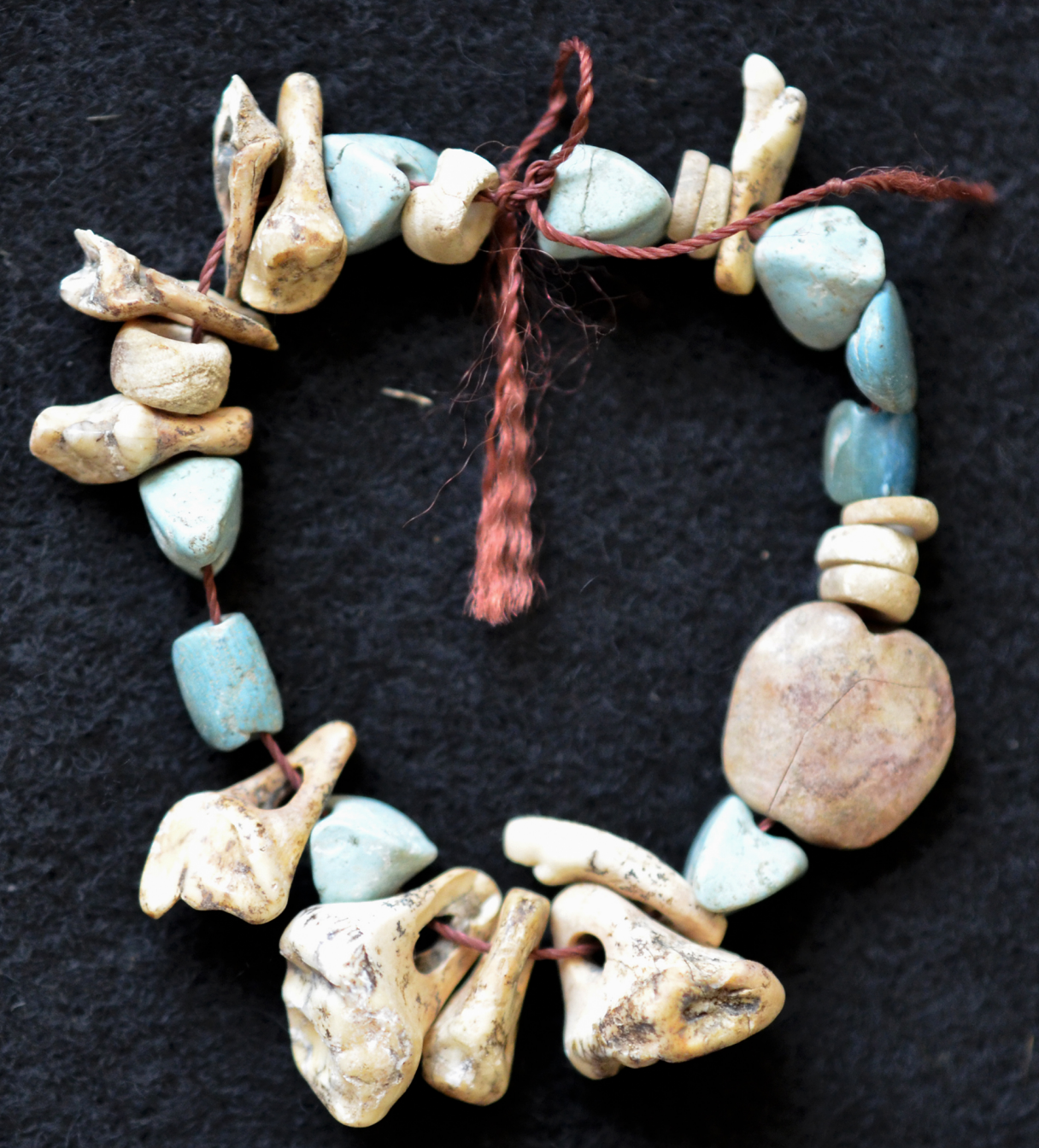

\section{0 000000} 0000 0000 $400:$
000000 \begin{tabular}{|l|l|}
\hline $\mathrm{Cm}$ & $\square$ \\
\hline
\end{tabular} 


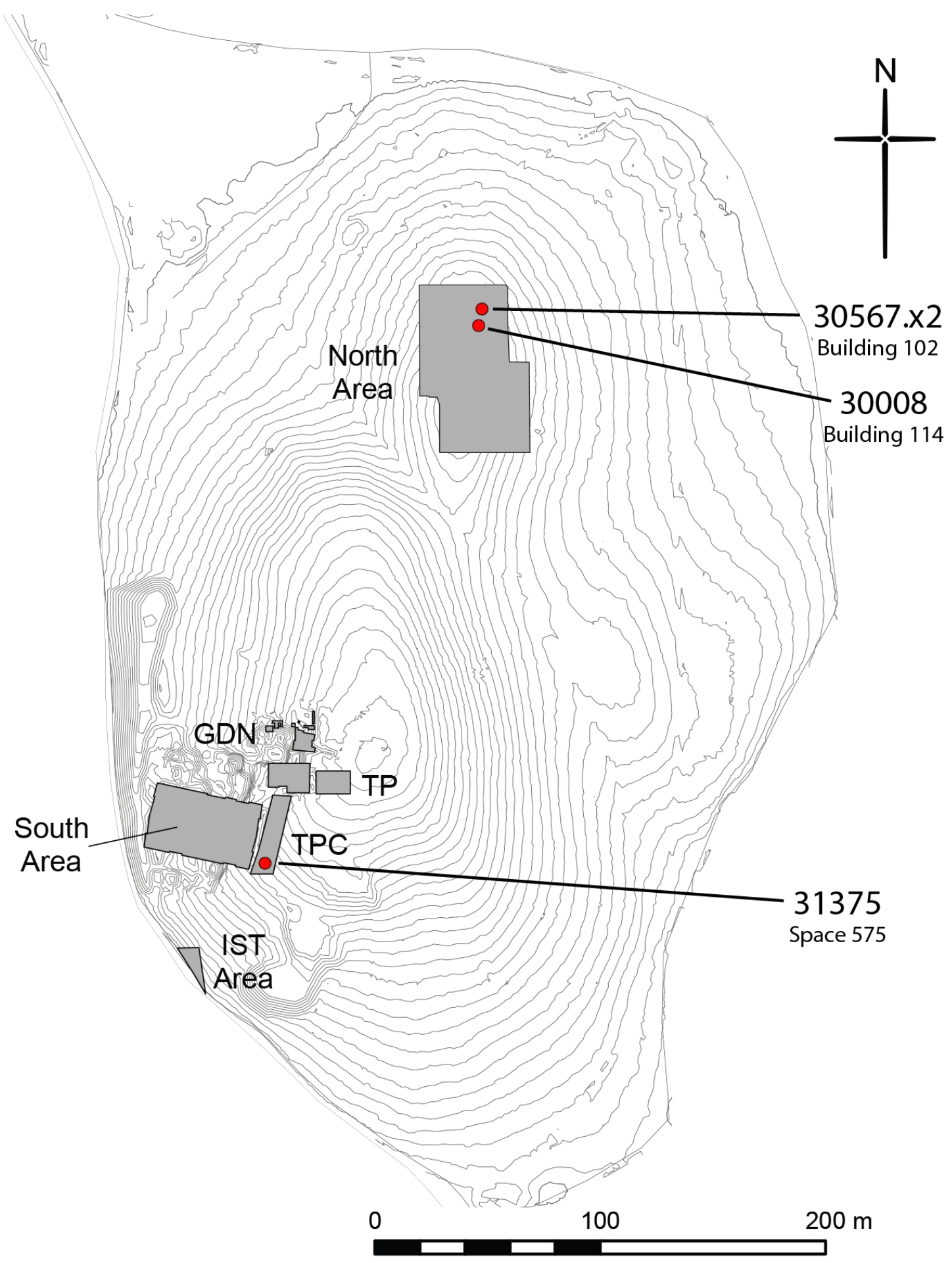

Çatalhöyük GIS 2019 

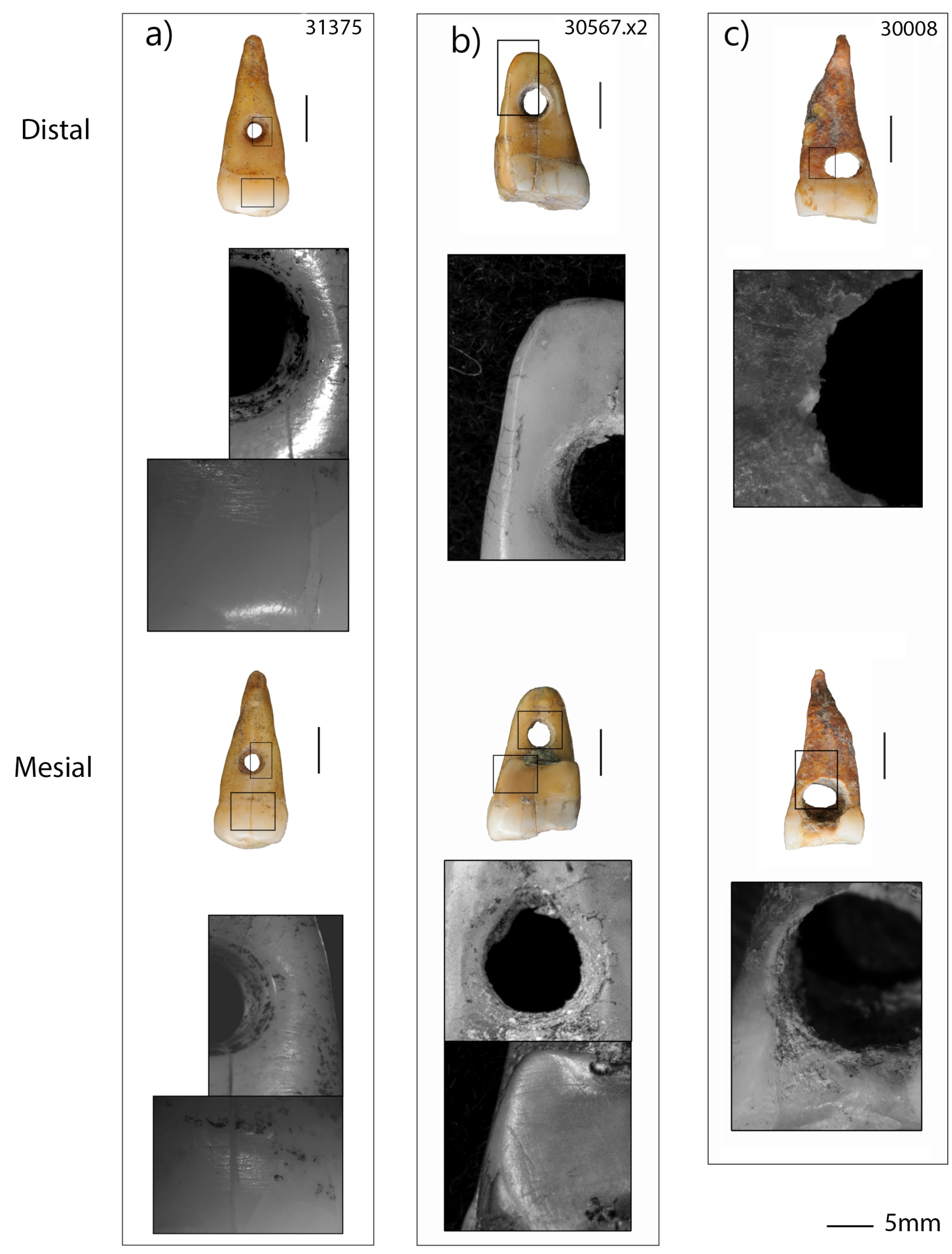

$5 \mathrm{~mm}$ 
MA

---- OA
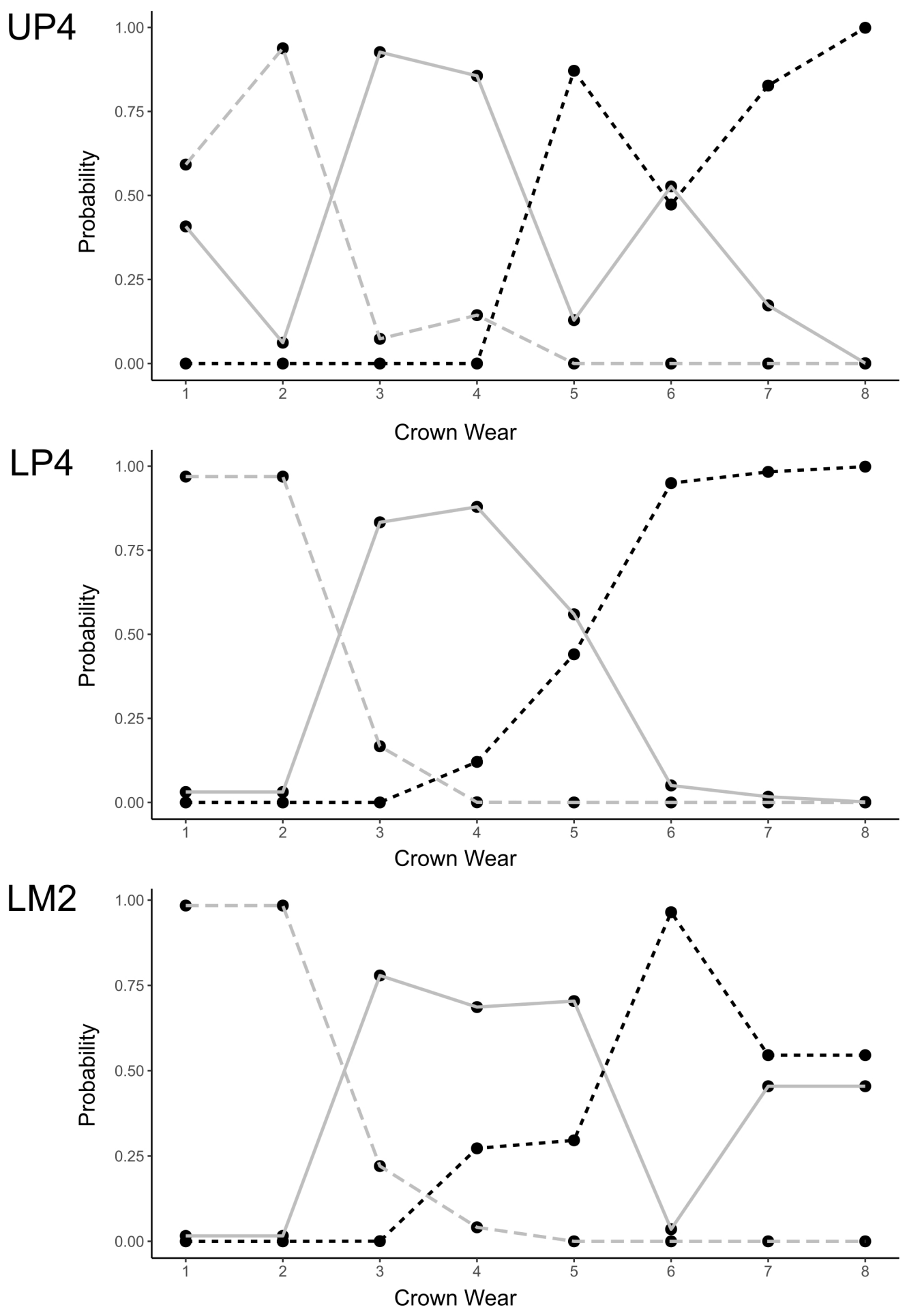


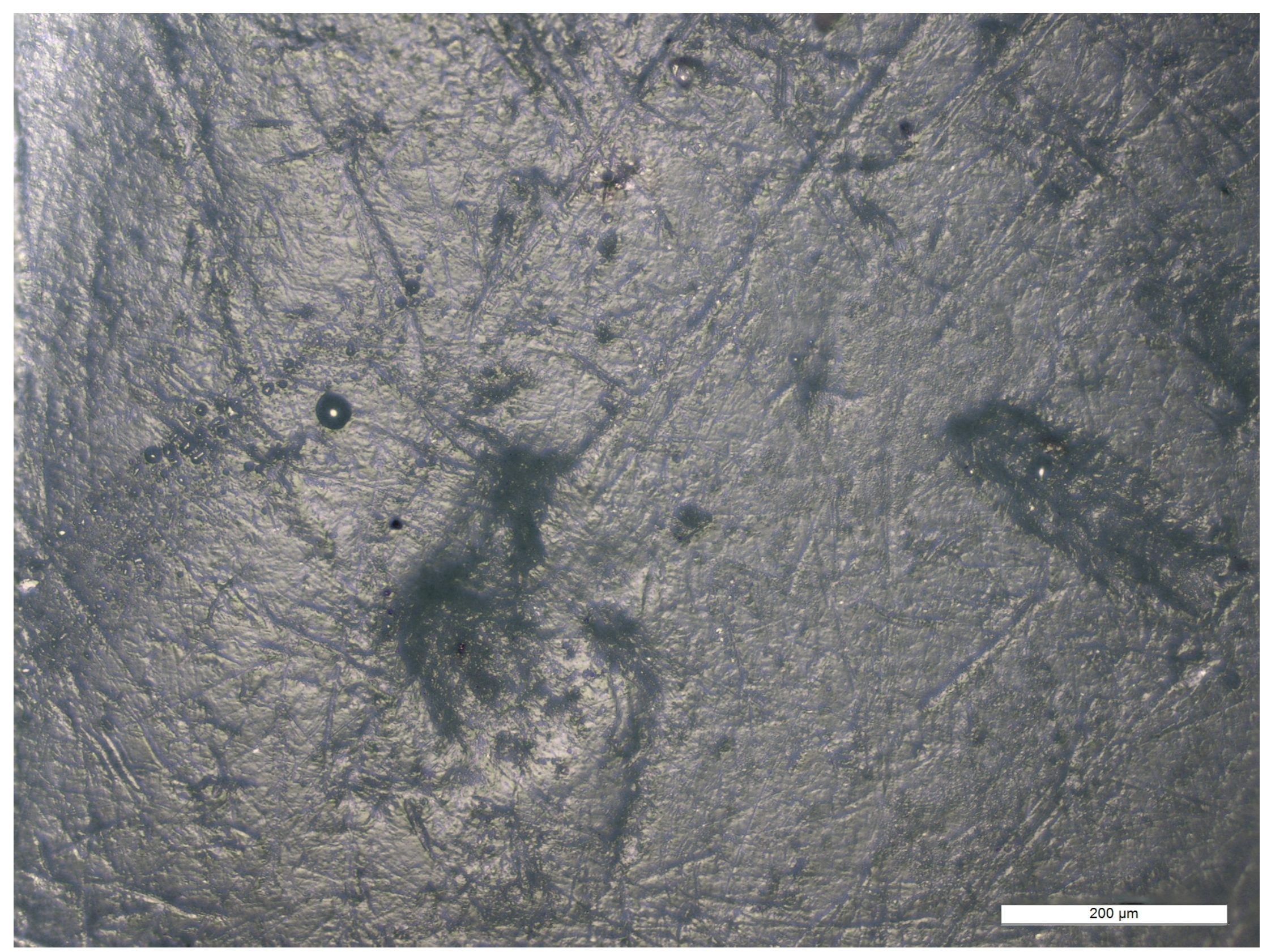




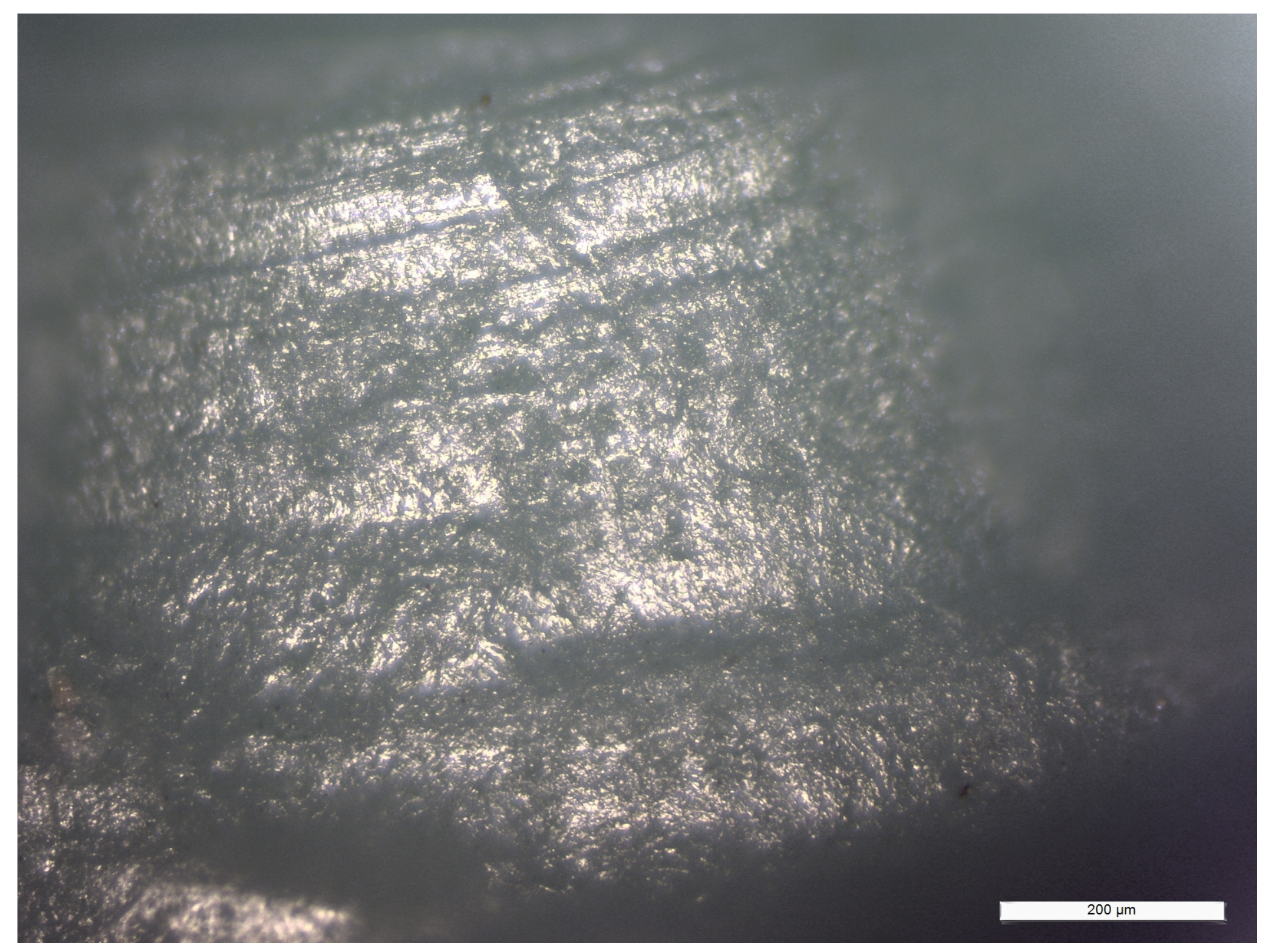


a) 31375
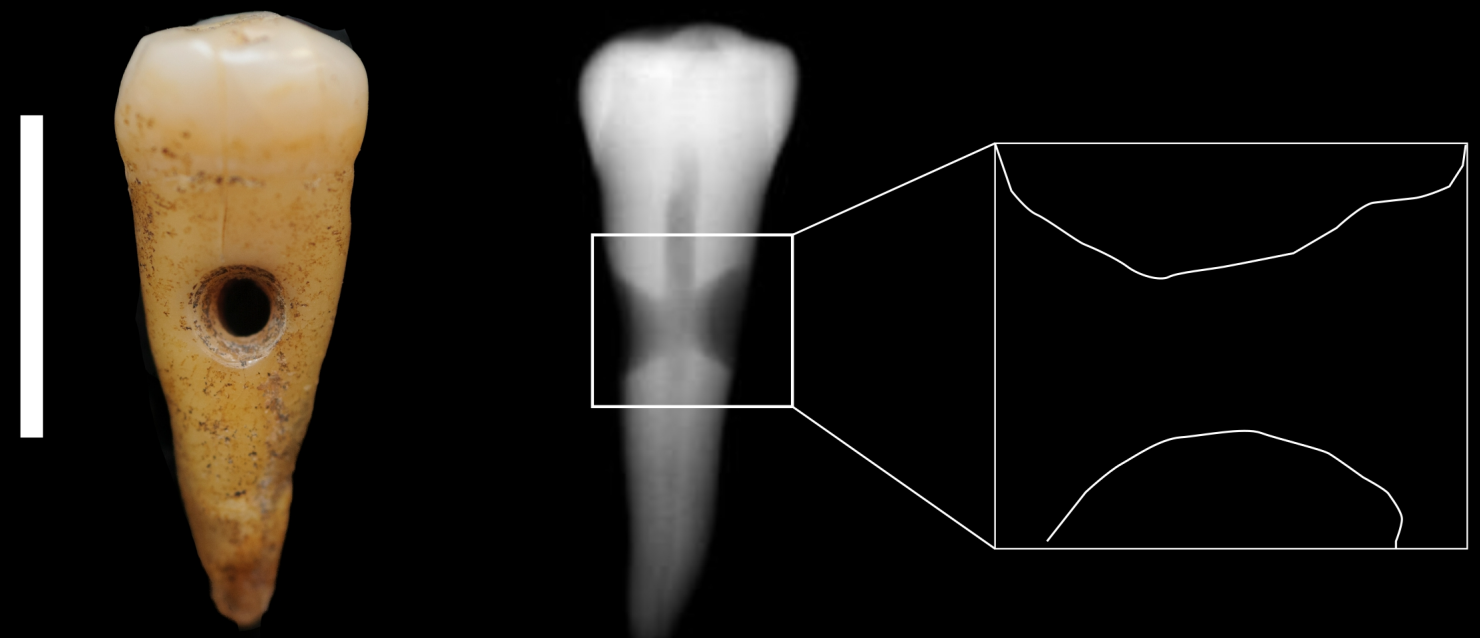

b) 30008
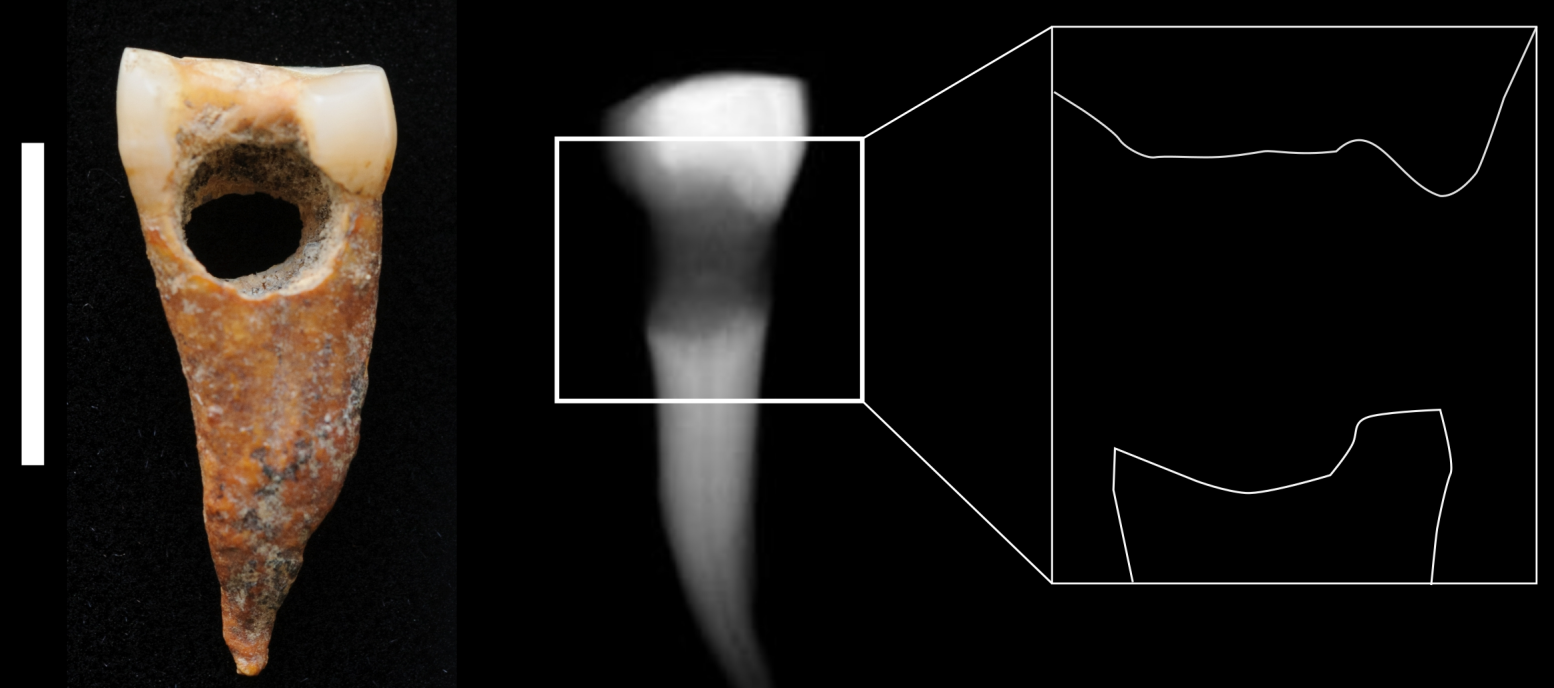

$10 \mathrm{~mm}$ 